\title{
AP-1 Transcription Factors Mediate BDNF-Positive Feedback Loop in Cortical Neurons
}

\author{
Jürgen Tuvikene, Priit Pruunsild, Ester Orav, Eli-Eelika Esvald, and Tõnis Timmusk \\ Department of Gene Technology, Tallinn University of Technology, 12618 Tallinn, Estonia
}

Brain-derived neurotrophic factor (BDNF), a member of the neurotrophin family, regulates both survival and differentiation of several neuronal populations in the nervous system during development, as well as synaptic plasticity in the adult brain. BDNF exerts its biological functions through its receptor TrkB. Although the regulation of $B D N F$ transcription by neuronal activity has been widely studied, little is known about TrkB signaling-dependent expression of $B D N F$. Using rat primary cortical neuron cultures, we show that the $B D N F$ gene is a subject to an extensive autoregulatory loop, where TrkB signaling upregulates the expression of all major BDNF transcripts, mainly through activating MAPK pathways. Investigating the mechanisms behind this autoregulation, we found that AP-1 transcription factors, comprising Jun and Fos family members, participate in the induction of BDNF exon I, III, and VI transcripts. AP-1 transcription factors directly upregulate the expression of exon I transcripts by binding two novel AP-1 cis-elements in promoter I. Moreover, our results show that the effect of AP-1 proteins on the activity of rat BDNF promoters III and VI is indirect, because AP-1 proteins were not detected to bind the respective promoter regions by chromatin immunoprecipitation (ChIP). Collectively, we describe an extensive positive feedback system in $B D N F$ regulation, adding a new layer to the elaborate control of $B D N F$ gene expression.

Key words: AP-1; BDNF autoregulation; BDNF-positive feedback loop; Fos; Jun; TrkB

Significance Statement

Here, we show for the first time that in rat primary cortical neurons the expression of all major BDNF transcripts (exon I, II, III, IV, VI, and IXa transcripts) is upregulated in response to TrkB signaling, and that AP-1 transcription factors participate in the induction of exon I, III, and VI transcripts. Moreover, we have described two novel functional AP-1 cis-elements in BDNF promoter I, responsible for the activation of the promoter in response to TrkB signaling. Our results indicate the existence of a positive feedback loop for obtaining sufficient BDNF levels necessary for various TrkB signaling-dependent physiological outcomes in neurons.

\section{Introduction}

Brain-derived neurotrophic factor (BDNF) is a secretory protein belonging to the neurotrophin family (Huang and Reichardt,

Received Sept. 8, 2015; revised Dec. 17, 2015; accepted Dec. 21, 2015.

Author contributions: J.T., P.P., and T.T. designed research; J.T., P.P., E.0., and E.-E.E. performed research; J.T., P.P., E.O., E.-E.E., and T.T. analyzed data; J.T., P.P., and T.T. wrote the paper.

This work was supported by Estonian Research Council (institutional research funding IUT19-18 and Grant ETF8844), National R\&D program "Biotechnology" (Grant AR12030), Estonian Enterprise (Grant EU27553), Norwegian Financial Mechanism (GrantEMP128), and Estonian Academy of Sciences. We thank Epp Väli and Maila Rähn for technical assistance, and Indrek Koppel for critical reading of the paper.

The authors declare no competing financial interests.

Correspondence should be addressed to either Tõnis Timmusk or Jürgen Tuvikene, Department of Gene Technology, Tallinn University of Technology, Akadeemia tee 15, 12618 Tallinn, Estonia, E-mail: tonis.timmusk@ttu.ee or jurgen.tuvikene@ttu.ee.

P. Pruunsild's present address: Department of Neurobiology, Interdisciplinary Center for Neurosciences (IZN), University of Heidelberg, 69120 Heidelberg, Germany.

E. Orav's present address: Neuroscience Center and Department of Biosciences, University of Helsinki, 00014 Helsinki, Finland.

DOI:10.1523/JNEUROSCI.3360-15.2016

Copyright $\odot 2016$ the authors $\quad 0270-6474 / 16 / 361290-16 \$ 15.00 / 0$
2001). BDNF binds to two distinctive classes of receptors, receptor tyrosine kinase subfamily member TrkB and tumor necrosis factor receptor superfamily member $\mathrm{p} 75^{\mathrm{NTR}}$, with mature BDNF preferentially binding to the TrkB receptor and proBDNF to the p75 ${ }^{\text {NTR }}$ receptor (Lu et al., 2005). During development, BDNF functions as a differentiation and survival factor for various populations of neurons in the peripheral nervous system and CNS, strictly regulating the number of neurons needed for proper functioning of the nervous system (Bibel and Barde, 2000; Huang and Reichardt, 2001; Park and Poo, 2013). In the adult brain, BDNF has an important role in long-term potentiation (LTP) and memory formation (for review, see Park and Poo, 2013). Dysregulation of BDNF expression is implicated in various neuropsychiatric disorders, indicating the importance of BDNF in higher cognitive functions and mood regulation (for review, see Autry and Monteggia, 2012).

$B D N F$ has a complex gene structure (Timmusk et al., 1993), with the rodent BDNF gene consisting of one protein-coding $3^{\prime}$ exon that is spliced together with one of the eight noncoding $5^{\prime}$ 
exons (Aid et al., 2007). In humans, two additional exons (Vh and VIIIh) have been described (Pruunsild et al., 2007). Each of the 5' exons, except the human cassette exons VIII, VIIIh, and IXb, has its own promoter, allowing complex spatiotemporal regulation of $B D N F$ expression in different brain regions and peripheral tissues throughout development (Aid et al., 2007; Pruunsild et al., 2007) and in response to various stimuli (Metsis et al., 1993; Karpova et al., 2010; Salerno et al., 2012; Baj et al., 2013).

AP-1 transcription factors, consisting of Fos and Jun family members, are immediate early genes, whose expression in the CNS is induced by various stimuli, including hypoxia, sensory stimulation, neurotransmitters, neurotrophins, and other growth factors (Sheng and Greenberg, 1990; Radler-Pohl et al., 1993; Karin et al., 1997; Herdegen and Leah, 1998). AP-1 proteins have a conserved basic leucine zipper domain, where the leucine zipper mediates protein dimerization and the basic region is responsible for binding to DNA (Eferl and Wagner, 2003). AP-1 transcription factors preferentially bind to the AP-1 element (also known as TRE, TPA-response element), with consensus sequence TGAC/GTCA (Eferl and Wagner, 2003). As with other basic leucine zipper domain-containing transcription factors, AP-1 proteins can bind DNA only as dimers, and binding to DNA greatly increases the dimer stability (Patel et al., 1994). Whereas Fos family proteins (c-Fos, FosB, Fra1, Fra2) are unable to form homodimers (Halazonetis et al., 1988; Shaulian and Karin, 2001), members of the Jun family (c-Jun, JunB, JunD) are able to form both homodimers and heterodimers within the family, and heterodimers with Fos family proteins or with other transcription factors, such as members of the ATF family, C/EBP, and others (Herdegen and Leah, 1998; Chinenov and Kerppola, 2001).

There is evidence suggesting that AP-1 proteins play a role in synaptic plasticity and memory (for review, see Alberini, 2009). For instance, AP-1 proteins have been implicated in both memory formation (Grimm et al., 1997) and consolidation of addictive behavior (Raivich and Behrens, 2006; Pérez-Cadahía et al., 2011). AP-1 proteins also regulate neuronal survival and apoptosis, with the outcome depending on the exact cellular context and stimulus (Herdegen and Leah, 1998).

Although the mechanisms of calcium- and neuronal activitydependent BDNF expression have been widely studied (for review, see West et al., 2014), little is known about TrkB signaling-dependent regulation of BDNF gene expression, with the main focus having been on studying the regulation of exon IV transcripts (Yasuda et al., 2007; Zheng and Wang, 2009; BambahMukku et al., 2014). Here, we show for the first time that in rat primary cortical neurons, the expression of all major BDNF transcripts is induced in response to TrkB signaling, and that part of this positive feedback loop is dependent on AP-1 family transcription factors.

\section{Materials and Methods}

Primary neuron cultures. All animal procedures were performed in compliance with the local ethics committee. Preparation of rat primary neuron cultures was performed as follows. Cortices and hippocampi of both male and female embryonic day (E)20-E21 Sprague Dawley rat pups were dissected, cells were dissociated using trypsin-EDTA ( $0.25 \%$ trypsin, $1 \mathrm{~mm}$ EDTA, Life Technologies) for $20 \mathrm{~min}$ at $37^{\circ} \mathrm{C}$, washed once with $1 \times$ HBSS, and treated with $0.05 \%$ DNase I (Roche) solution in $1 \times$ HBSS (including $12 \mathrm{~mm} \mathrm{MgSO}_{4}$ ) for $5 \mathrm{~min}$ at $37^{\circ} \mathrm{C}$. After washing with $1 \times$ HBSS again, solution of $0.1 \%$ trypsin inhibitor (AppliChem) and $1 \%$ BSA (Sigma-Aldrich) in $1 \times$ HBSS was added and cortices and hippocampi were triturated using flame-polished Pasteur pipette. Undissociated tissue clumps were allowed to sediment by gravity for 3-5 min, supernatant was moved to a new tube and centrifuged at $200 \times g$ for 5 min. Neurons were resuspended in prewarmed Neurobasal A medium (Invitrogen) containing $1 \times$ B27 supplement (Invitrogen), $1 \mathrm{~mm}$ L-glutamine (PAA Laboratories), $100 \mathrm{U} / \mathrm{ml}$ penicillin (PAA Laboratories), and $0.1 \mathrm{mg} / \mathrm{ml}$ streptomycin (PAA Laboratories), and plated on culture plates previously coated with $0.2 \mathrm{mg} / \mathrm{ml}$ poly-L-lysine (SigmaAldrich) in borate buffer, $\mathrm{pH}$ 8.5. At $2 \mathrm{~d}$ in vitro (DIV), one-half of the medium was replaced with fresh medium, containing 5-fluoro-2'deoxyuridine (10 $\mu \mathrm{m}$ final concentration, Sigma-Aldrich) to inhibit proliferation of glial cells.

Cloning and mutagenesis. Full-length coding sequences of AP-1 genes were amplified from either human genomic DNA or from human cDNA, for Jun family and Fos family members, respectively, using Phusion Hot Start II High-Fidelity DNA Polymerase (Thermo Scientific). For expression in eukaryotic cells, the protein coding sequences of AP-1 genes were cloned into $\mathrm{PQM}$ vector backbone (Icosagen) after murine phosphoglycerate kinase 1 (PGK) promoter (mouse genome assembly GRCm38/ mm10, chromosome X region 106186727-106187231). The sequence coding for VP16 transactivation domain was obtained from pACT vector (Promega), the sequence coding for V5-tag was obtained from pcDNA3.1 vector (Invitrogen), to make vectors coding for VP16- or V5-tagged AP-1 proteins, respectively. Plasmid encoding A-Fos was obtained from Addgene (plasmid 33353).

The rat and human $B D N F$ promoter I reporter constructs and the respective plasmids with mutated AP1-1 and PasRE site have been described previously (Pruunsild et al., 2011). For amplifying human and rat BDNF promoter III and VI regions from genomic DNA, Phusion Hot Start II HighFidelity DNA polymerase (Thermo Scientific) was used. The respective promoter regions were cloned upstream of firefly luciferase-coding sequence into pGL4.15 [Luc2P/Hygro] vector (Promega).

Site-directed mutagenesis was performed using complementary primers containing the desired mutation and Phusion Hot Start II DNA polymerase. After PCR, sample was treated with $0.5 \mathrm{U} / \mu \mathrm{l}$ DpnI restriction enzyme (Thermo Scientific) for at least $1 \mathrm{~h}$ at $37^{\circ} \mathrm{C}$ to digest parental DNA template, and transformed into TOP10 competent cells (Invitrogen). All constructs were verified by sequencing.

Treatments and RT-qPCR. At 7-8 DIV, as indicated below each figure, primary neurons were treated with $50 \mathrm{ng} / \mathrm{ml}$ human recombinant BDNF (Peprotech). Where indicated, cells were pretreated with inhibitors of different signaling pathways for 30 min before adding BDNF to the medium. Final concentrations of the compounds were as follows: $0.1 \%$ DMSO (SigmaAldirch), $10 \mu \mathrm{M}$ U0126 (Tocris Bioscience), $10 \mu \mathrm{M}$ Bix02189 (Axon Medchem), $1 \mu \mathrm{M}$ PD184352 (Sigma-Aldrich), $25 \mathrm{~nm} \mathrm{Az-23} \mathrm{(Axon} \mathrm{Medchem),} 10$ $\mu \mathrm{M}$ Go6983 (Tocris Bioscience), $100 \mathrm{~nm}$ Wortmannin (Millipore), $1 \mu \mathrm{M}$ U73122 (Cayman Europe). Total RNA was isolated using RNeasy Micro or Mini kit (Qiagen) according to the manufacturer's protocol.

For human embryonic kidney HEK293 cell-line, cells grown on sixwell plate were transfected using LipoD293 DNA In Vitro Transfection Reagent (SignaGen) according to the manufacturer's instruction, using 3 $\mu \mathrm{g}$ of DNA and a ratio of 1:2 DNA-LipoD293 per well. Forty-eight hours after transfection, cells were lysed and RNA was isolated using RNeasy Mini kit (Qiagen).

First strand cDNA was synthesized from 500 to $2000 \mathrm{ng}$ or $5 \mu \mathrm{g}$ of RNA, for primary neurons or HEK293, respectively, using oligo $(\mathrm{dT})_{20}$ primer and Superscript III Reverse Transcriptase (Invitrogen) as recommended by the manufacturer. Quantitative PCR (qPCR) reactions were performed in triplicates using LightCycler 480 SYBR Green I Master qPCR mix (Roche) on LightCycler 480 II Real Time PCR System (Roche). Levels of HPRT1 mRNA were used to normalize qPCR data. Before statistical analysis, normalized data were log-transformed and autoscaled using data of all time points for the respective transcripts (Fig. $1 A$ ), or using data of the respective transcripts in DMSO-treated neurons that were left untreated or treated with BDNF for $3 \mathrm{~h}$ (Fig. $1 B, C$ ). For graphical representation, data were backtransformed, with error bars representing upper and lower limits of backtransformed mean \pm SEM.

Primer sequences used to amplify rat $H P R T 1$ and rat $B D N F$ transcripts have been described previously (Kairisalo et al., 2009). For amplifying human HPRT1 and human BDNF (hBDNF) transcripts, the following primers were used: human HPRT1 (forward: GCCAGACTTTGTTGGATTTG, reverse: CTCTC ATCTTAGGCTTTGTATTTTG), hBDNF exon I (forward: AACAAGA 

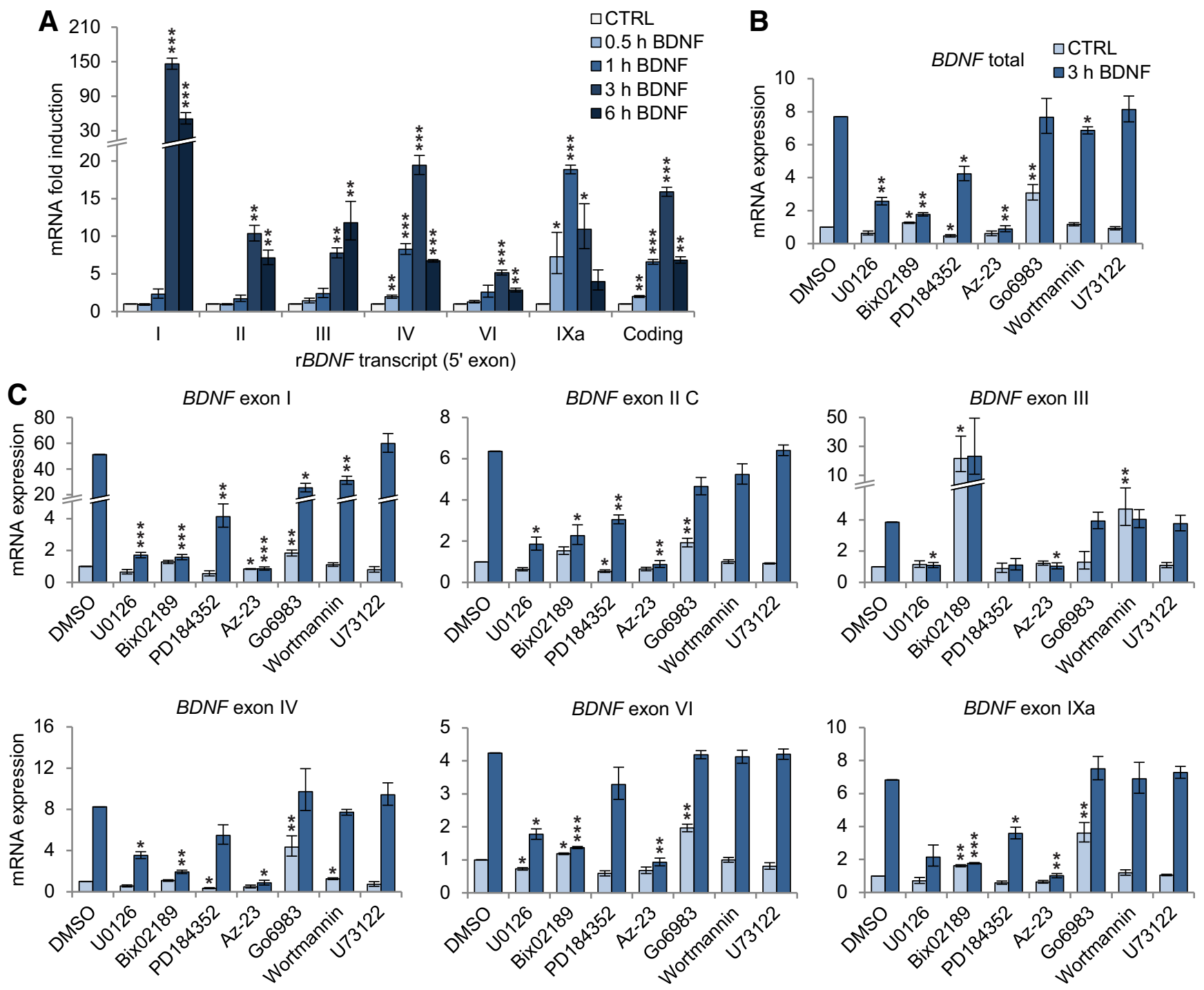

Figure 1. TrkB signaling induces $r B D N F m R N A$ expression in primary cortical neurons. $A$, Expression of all measured $B D N F$ transcripts is induced by TrkB signaling. At 7 DIV, rat primary cortical neurons were treated with $50 \mathrm{ng} / \mathrm{ml}$ BDNF for the time indicated; endogenous BDNF mRNA levels were measured using RT-qPCR with primers specific for transcripts with the respective $5^{\prime}$ exons, or primers against coding region to measure total $B D N F m R N A$. $m R N A$ levels are shown as fold induction relative to the levels of the respective transcripts in untreated cells (CTRL). B, C, BDNF induction in response to TrkB signaling is mediated mainly by the MAPK pathway. Inhibitors of different signaling pathways (10 $\mu \mathrm{m}$ U0126, $10 \mu \mathrm{m}$ Bix02189, 1 $\mu \mathrm{M}$ PD184352, $25 \mathrm{~nm} \mathrm{Az}-23,10 \mu \mathrm{m}$ G06983, $100 \mathrm{~nm}$ Wortmannin, $1 \mu \mathrm{m}$ U73122) or vehicle (0.1\% DMSO) was added to the culture medium 30 min before treating primary neurons with $50 \mathrm{ng} / \mathrm{ml}$ BDNF for $3 \mathrm{~h}$ at 7 DIV. BDNF expression was measured using RT-qPCR. For each transcript, mRNA levels are shown relative to the respective transcript's $\mathrm{mRNA}$ expression in cells treated with vehicle and not treated with BDNF. Error bars represent SEM of at least three independent experiments in $\boldsymbol{A}-\boldsymbol{C}$. Asterisks indicate statistical significance relative to the respective transcript's untreated control $(\boldsymbol{A})$, or relative to the respective transcript levels in cells treated with DMSO and either left untreated or treated with BDNF for $3 \mathrm{~h}$, respectively $(\boldsymbol{B}, \boldsymbol{C}) .{ }^{*} p<0.05,{ }^{* *} p<0.01,{ }^{* * *} p<0.001 ; t$ test on log-transformed and autoscaled data.

CACATTACCTTCCAGCAT, reverse: CTCTTCTCACCTGGTGGAACATT), $\mathrm{h} B D N F$ exon III (forward: TGGCTTAGAGGGTTCCCGCT, reverse: ATGGGGGCAGCCTTCATGCA), hBDNF exon IV (forward: GAAGTC TTTCCCGGAGCAGCT, reverse: ATGGGGGCAGCCTTCATGCA), and hBDNF exon VI (forward: GGTTTGTGTGGACCCCGAGTTC, reverse ATGGGGGCAGCCTTCATGCA).

Western blot analysis. For Western blot analysis, primary neurons were lysed in $1 \times$ Laemmli buffer. Proteins were separated using SDSPAGE and transferred to PVDF membrane (Millipore) using TransBlot SD SemiDry Transfer Cell (Bio-Rad). Membranes were blocked in $1 \times$ PBS containing $5 \%$ skimmed milk and $0.1 \%$ Tween 20 for $1 \mathrm{~h}$ at room temperature, followed by incubation with primary antibody in $1 \times$ PBS containing $2 \%$ skimmed milk and $0.1 \%$ Tween 20 for $1 \mathrm{~h}$ at room temperature or overnight at $4^{\circ} \mathrm{C}$. Next, membranes were washed $3 \times 5$ min with $0.1 \%$ Tween 20 solution in $1 \times$ PBS. Blots were incubated with secondary antibody for $1 \mathrm{~h}$ at room temperature in $1 \times$ PBS containing $2 \%$ skimmed milk and $0.1 \%$ Tween 20 . Membranes were washed $3 \times 5$ min and chemiluminescence signal was detected using SuperSignal West Femto Chemiluminescence Substrate (Thermo Scientific) and ImageQuant LAS 4000 bioimager (GE Healthcare).

Antibodies against AP-1 family proteins were obtained from Santa Cruz Biotechnology: c-Jun (1:5000, sc-1694x, H2808), JunB (1:5000, sc8051x, B1611), JunD (1:5000, sc-74x, G1911), c-Fos (1:5000, sc-7202x, C3108), FosB (1:5000, sc-48x, K1811), Fra1 (1:5000, sc-605x, G1612), and Fra2 (1:1000, sc-604x, G1911). GAPDH antibody was from Millipore (1:5000, MAB374, lot 2506322). Stabilized Goat Anti-Mouse IgG $(\mathrm{H}+\mathrm{L})$ Peroxidase-Conjugated (32430) and Stabilized Goat Anti-Rabbit IgG $(\mathrm{H}+\mathrm{L})$ Peroxidase-Conjugated (32460) secondary antibodies (1: 5000 dilution) used in Western blot analysis were purchased from Thermo Scientific.

Transduction using adeno associated virus vectors. Adeno associated virus (AAV) virions coding EGFP or A-Fos under the control of human Synapsin I promoter were prepared as described previously (Koppel et 
al., 2015). Titer of infectious particles was assessed by immunocytochemistry using either anti-EGFP antibody (a kind gift from Andres Merits, Institute of Technology, University of Tartu, Tartu, Estonia) or antiFLAG antibody (F1804, Sigma-Aldrich). Primary neurons were infected with two to three multiplicity of infection at 2 DIV, immunocytochemistry, and Western blot analysis or BDNF treatment and RNA extraction were performed at 8 DIV. RT-qPCR data were log-transformed and autoscaled using data of the respective transcripts in neurons infected with AAV-EGFP. Statistical analysis was performed on autoscaled data. For graphical representation, data were backtransformed to linear scale, with error bars indicating upper and lower limits of backtransformed mean \pm SEM.

DNA transfection and luciferase reporter assay. For luciferase reporter assay, neurons grown on 48-well plates were transfected at 6 DIV using Lipofectamine 2000 (Invitrogen) reagent according to the manufacturer's recommendations. Lipofectamine-DNA ratio of 2:1 was used, with $0.5 \mu \mathrm{g}$ of DNA per well. Where applicable, $B D N F$ promoter construct and plasmids coding effector proteins or empty $\mathrm{PQM}$ vector were cotransfected at 1:1 ratio. For normalization, 20 ng pPGK/pGL4.83 plasmid, expressing Renilla luciferase under the control of murine $P G K$ promoter, was cotransfected per well.

At 7 DIV, neurons were treated with $50 \mathrm{ng} / \mathrm{ml}$ human recombinant BDNF (Peprotech). Cells were lysed after $8 \mathrm{~h}$ of BDNF treatment using $1 \times$ Passive Lysis Buffer (Promega) and luciferase assays were performed using Dual-Glo Luciferase Assay System (Promega). Luminescence was measured in duplicate samples using GeniOS Pro (Tecan). For presenting data in relative luciferase units (RLUs), background signal from untransfected neurons was subtracted from both firefly luciferase (FFLuc) and Renilla luciferase (RLuc) signals. Background corrected FFLuc signals were normalized using RLuc signals. Normalized data were logtransformed and autoscaled using data of wild-type (WT) promoter construct (cotransfected with empty pQM vector, where applicable). For statistical analysis, autoscaled data were used. For graphical representation of results, means, and mean \pm SEM of autoscaled data were calculated and backtransformed to linear scale. Error bars represent upper and lower limits of backtransformed mean \pm SEM.

Electrophoretic mobility shift assay. For preparation of cell lysates, neurons grown for 7 DIV on a $10 \mathrm{~cm}$ dish were washed with $1 \times$ PBS and collected in $200 \mu \mathrm{l}$ ice-cold sonication buffer containing $20 \mathrm{mM}$ HEPES$\mathrm{KOH}, \mathrm{pH} 7.9,25 \%$ glycerol, $500 \mathrm{~mm} \mathrm{KCl,} 1.5 \mathrm{~mm} \mathrm{MgCl}_{2}, 0.4$ mм EDTA, 1 mм EGTA, 5 mм DTT, 0.5 mm PMSF, $1 \times$ cOmplete Protease Inhibitor Cocktail (Roche), and $1 \times$ PhosSTOP Phosphatase Inhibitor Cocktail (Roche). Lysates were then incubated on ice for $15 \mathrm{~min}$, sonicated until no viscous matter remained, and centrifuged at $4^{\circ} \mathrm{C}$ and $16,100 \times g$ for 10 min. Aliquots of supernatant were snap-frozen in liquid nitrogen and stored at $-80^{\circ} \mathrm{C}$

Oligonucleotides ( $5 \mathrm{pmol}$ per reaction) were labeled with T4 polynucleotide kinase (Thermo Scientific) using ATP $\gamma-{ }^{32} \mathrm{P}$ (PerkinElmer). After labeling, sense and antisense oligonucleotides were annealed in annealing buffer ( $50 \mathrm{~mm} \mathrm{NaCl}, 1 \mathrm{~mm}$ EDTA, $0.2 \times$ PNK buffer A, $100 \mu \mathrm{l}$ total volume) by placing the tubes in a $95^{\circ} \mathrm{C}$ water bath and allowed to cool to room temperature overnight. Annealed oligonucleotides were separated from unincorporated label using Sephadex G-50 (Pharmacia Fine Chemicals) resin.

Electrophoretic mobility shift assay (EMSA) binding reaction contained $\sim 10 \mu \mathrm{g}$ (estimated using BCA Protein Assay Kit; Pierce) crude whole-cell protein extract $(\sim 2.25 \mu$ l lysate), $1 \mu \mathrm{g}$ poly(dI-dC; SigmaAldrich), $0.1 \mathrm{mg} / \mathrm{ml} \mathrm{BSA}$ (Thermo Scientific), and $1 \times$ binding buffer (10 mм HEPES-KOH, pH 7.5, 0.5 mм EDTA, 2 mм $\mathrm{MgCl}_{2}, 0.05 \%$ NP-40, $4 \%$ Ficoll-400) in a total volume of $20 \mu \mathrm{l}$. Binding reactions were equilibrated on ice for $10-15 \mathrm{~min}$, followed by addition of $75 \mathrm{fmol}$ radioactive probe and an additional 20 min incubation at room temperature. For competition experiments, tenfold excess of unlabeled competitor was added $5 \mathrm{~min}$ before adding the probe. For supershift experiments, $1 \mu \mathrm{g}$ of antibody was added to the binding reaction and incubated for $1 \mathrm{~h}$ at room temperature before adding the probe. Electrophoresis was performed using $4-5 \%$ non-denaturing polyacrylamide gels containing $0.25 \times \mathrm{TBE}$ and $0.01 \% \mathrm{NP}-40$, with $0.5 \times \mathrm{TBE}$ as electrophoresis buffer.
ChIP. Neurons grown on $10 \mathrm{~cm}$ dishes were left untreated or treated with $50 \mathrm{ng} / \mathrm{ml} \mathrm{BDNF}$ for $2 \mathrm{~h}$ at 7 DIV. Following treatment, chromatin was crosslinked for 10 min using $1 \%$ formaldehyde, crosslinking reaction was quenched by adding a final concentration of $200 \mathrm{~mm}$ glycine to the medium and incubating for $10 \mathrm{~min}$. Cells were washed twice with $1 \times$ PBS and scraped together in ice-cold lysis buffer (1\% SDS, 10 mM EDTA, $50 \mathrm{~mm}$ Tris-HCl, $\mathrm{pH}$ 8.0, cOmplete Protease Inhibitor Cocktail, Roche). Lysates were kept on ice and sonicated to obtain DNA fragments of an average length $<1 \mathrm{kbp}$. After sonication, lysate was centrifuged for $5 \mathrm{~min}$ at $16100 \mathrm{~g}$ to remove insoluble material. Lysate protein content was measured using BCA Protein Assay kit (Pierce). Lysate (700-1000 $\mu \mathrm{g}$ protein per IP) was diluted 1:9 with dilution buffer ( $1 \%$ Triton X-100, $150 \mathrm{~mm} \mathrm{NaCl}, 2$ mм EDTA, 20 mm Tris-HCl, pH 8.0, cOmplete Protease Inhibitor Cocktail, Roche) and samples were rotated with $5 \mu \mathrm{g}$ pan-Fos antibody (Santa Cruz Biotechnology, sc-253x, K0110), c-Jun antibody (Santa Cruz Biotechnology, sc-1694x, H2808), or no antibody overnight at $+4^{\circ} \mathrm{C}$. Then, $50 \mu \mathrm{l}$ of $50 \%$ Protein A Sepharose CL-4B (GE Healthcare) slurry that had been preabsorbed with $200 \mu \mathrm{g} / \mathrm{ml} \mathrm{BSA}$ and $10 \mu \mathrm{g} / \mathrm{ml}$ sheared salmon sperm DNA overnight at $+4^{\circ} \mathrm{C}$, was added to each sample and rotated an additional $2-4 \mathrm{~h}$ at $+4^{\circ} \mathrm{C}$. Sepharose-chromatin complexes were washed four times with wash buffer ( $1 \%$ Triton X-100, $0.1 \%$ SDS, $150 \mathrm{~mm} \mathrm{NaCl}, 2$ mm EDTA, 20 mm Tris-HCl, pH 8.0, cOmplete Protease Inhibitor Cocktail, Roche), and once with final wash buffer ( $1 \%$ Triton X-100, 0.1\% SDS, 500 mм NaCl, 2 mм EDTA, 20 mм Tris- $\mathrm{HCl}$, pH 8.0, cOmplete Protease Inhibitor Cocktail, Roche). Immune complexes were eluted three times using $50 \mu$ l elution buffer (1\% SDS, 100 $\mathrm{mm} \mathrm{NaHCO}_{3}$ ); eluates from the same samples were combined. Chromatin was de-crosslinked by incubating samples with $250 \mathrm{~mm} \mathrm{NaCl}$ at $65^{\circ} \mathrm{C}$ overnight. DNA was purified using QIAquick PCR Purification Kit (Qiagen). Abundance of target genomic regions was quantified using qPCR with the following primers: rat $B D N F$ (rBDNF) promoter I (forward: ACGTCCGCTG GAGACCCTTAGT, reverse: GGCAGCCTCTCTGAGCCAGTTA), rBDNF promoter III (forward: TAGGTGAGAACCTGGGGCAA, reverse: CTTG AGCTTCCCCAACCTCG), rBDNF promoter IV (forward: ATGCAATGCC CTGGAACGGAA, reverse: CGGTGAATGGGAAAGTGGGTGG), rBDNF promoter VI (forward: CGCTGTCTGACCAATCGAAG, reverse: GTTTC CTTCTCCAAGCCGGG), rat matrix metallopeptidase 9 (MMP9) promoter (forward: CTTTGGGCTGCCCAACACACA, reverse: GAAGCAGAATTT GCGGAGGTTTT), unrelated region (forward: TAGACCCAGGAGGGA GTTATTTAAGAG, reverse: TTGGGAATGCAATGCAGTGTGTAC). Data were calculated as a percentage of immunoprecipitated DNA relative to the respective target levels in input DNA. Data were log-transformed, means and mean \pm SEM were calculated, and statistical analysis was performed. For graphical representation, data were backtransformed into linear scale with error bars representing backtransformed mean \pm SEM.

For ChIP analysis in HEK293 cells, cells grown on $10 \mathrm{~cm}$ dishes were transfected with polyethylenimine (PEI), using $10 \mu \mathrm{g}$ DNA per $10 \mathrm{~cm}$ dish and DNA:PEI ratio of 1:2. Twenty-four hours after transfection, chromatin was fixed and cells were lysed as with primary neurons. Lysate made from cells grown on one $10 \mathrm{~cm}$ dish was used per IP, $50 \mu \mathrm{l}$ of anti-V5 agarose $50 \%$ slurry (Sigma-Aldrich) that had been preabsorbed with $200 \mu \mathrm{g} / \mathrm{ml} \mathrm{BSA}$ and $10 \mu \mathrm{g} / \mathrm{ml}$ sheared salmon sperm DNA, was used per sample and rotated overnight at $4{ }^{\circ} \mathrm{C}$. Washes and elution were performed as with ChIP analysis from lysates of primary neurons. The following primers were used to quantify immunoprecipitated DNA regions with qPCR: hBDNF promoter I (forward: TCACGACCTCATCGGCTGGA, reverse: GACGACTAACCTCGCTGTTT), hBDNF promoter IV (forward: CTGGTAATTCGTGCACTAGAGT, reverse: CACGAGAGGGCTCCACG GT), human metallothionein $2 A$ (MT2A) promoter (forward: GTTCGCT GGGACTTGGAGG, reverse: ACTCGTCCCGGCTCTTTCTA), unrelated region (forward: GTCATGAGGGCTCCACTCTTA, reverse: AAGGGCAAAGAGGGCAACAGA). Data were normalized to the levels of the respective target in input DNA and calculated as fold induction relative to the respective levels in pQM transfected cells. Data were log-transformed and autoscaled, means and mean \pm SEM were calculated, and statistical analysis was performed. For graphical representation, data were backtransformed into linear scale with error bars representing backtransformed mean \pm SEM.

Statistical analysis. For statistical analysis, all data were log-transformed to obtain normal distribution of the data. Where noted in figure 
legends, log-transformed data were autoscaled according to Willems et al. (2008) before statistical analysis, to account for variations between biological replicates. As the data does not meet ANOVA's requirement of homoscedasticity (due to normalization and autoscaling, the control groups have zero variance), two-tailed unequal variance $t$ test (Welch's $t$ test) was used on log-transformed data instead of ANOVA. Only hypothesis specified a priori were tested for statistical significance. To preserve the power of statistical analysis, $p$ values were left uncorrected for multiple comparisons as recommended by Rothman (1990), Feise (2002), and Streiner and Norman (2011). Differences were considered statistically significant when $p<0.05$. In all experiments, data are presented as mean \pm SEM.

\section{Results}

Expression of BDNF mRNA in rat primary cortical neurons is induced in response to TrkB signaling

To investigate $B D N F$ gene autoregulation and to determine the temporal pattern of TrkB signaling-induced BDNF mRNA transcription, we used rat primary cortical neuron cultures. At 7 DIV, neurons were either left untreated or treated with $50 \mathrm{ng} / \mathrm{ml} \mathrm{BDNF}$ for $30 \mathrm{~min}$ to $6 \mathrm{~h}$, after which the levels of different BDNF transcripts were measured using RT-qPCR (Fig. 1A).

Our results showed that the expression of BDNF mRNA was strongly induced in response to BDNF treatment of primary neurons (Fig. $1 A$ ), with a $\sim 2$-fold induction seen already at $30 \mathrm{~min}$ and a peak induction of $\sim 16$-fold at $3 \mathrm{~h}$ of BDNF treatment, after which the levels started to decline. Next, we measured the expression of different BDNF transcripts and found that the expression of exon I, II, III, IV, VI, and IXa transcripts was induced after treating primary neurons with BDNF. The expression of exon $\mathrm{V}$ transcripts was too low to measure reliably.

The induction of exon IV transcripts was similar to that of total BDNF mRNA, which is in accordance with the fact that exon IV-containing transcripts are the most abundant BDNF transcripts in the rat cerebral cortex (Timmusk et al., 1994; Aid et al., 2007 ), thus comprising the majority of total BDNF mRNA measured. A statistically significant $\sim 2$-fold increase in the expression of exon IV transcripts was seen at $30 \mathrm{~min}$, and a maximum induction of $\sim 19$-fold was detected after $3 \mathrm{~h}$ of BDNF treatment.

The overall temporal pattern of induction for exon I, II (II C, longest splice variant), and VI transcripts was similar, with a slight ( $\sim 2$-fold) but statistically insignificant induction after $1 \mathrm{~h}$ of treatment with BDNF, and a statistically significant maximum induction at $3 \mathrm{~h}$ of stimulation. The highest induction in response to BDNF was seen for exon I-containing transcripts, with a peak of $\sim 145$-fold increase at $3 \mathrm{~h}$. A moderate induction was seen for exon II transcripts $(\sim 10$-fold) and a low induction for exon VI transcripts $(\sim 5$-fold $)$ at $3 \mathrm{~h}$ time point. Interestingly, the levels of exon III-containing transcripts continued to rise, albeit statistically insignificantly ( $p=0.18$ for $6 \mathrm{~h}$ vs $3 \mathrm{~h}$ time point) even after $3 \mathrm{~h}$ of treatment, reaching $\sim 12$-fold induction at $6 \mathrm{~h}$.

Notably, the induction of exon IXa-containing transcripts showed a faster temporal pattern than other BDNF transcripts; a strong $\sim 7$-fold induction was seen already after 30 min of treatment, with a peak induction of $\sim 19$-fold at $1 \mathrm{~h}$, after which the levels of exon IXa transcripts started to decline.

Next, we decided to check which signaling pathways were responsible for the TrkB signaling-dependent BDNF mRNA induction. It is known that TrkB signaling activates three major pathways: MAPK cascade, PI-3K and AKT pathway, and PLC $\gamma 1$-dependent activation of PKC and intracellular calcium stores (Reichardt, 2006). Therefore, we applied inhibitors of these pathways $30 \mathrm{~min}$ before treating neurons for $3 \mathrm{~h}$ with BDNF. RNA was extracted and the expression levels of different $B D N F$ transcripts were measured using RT-qPCR (Fig. $1 B, C$ ). We found that Az-23, a potent Trk inhibitor
(Thress et al., 2009), abolished the BDNF-dependent BDNF mRNA induction, indicating that TrkB signaling, and not signaling through $\mathrm{p} 75^{\mathrm{NTR}}$, was responsible for the induction.

Using MAPK cascade inhibitors U0126 (MEK1 and MEK2 inhibitor), Bix02189 (ERK5 inhibitor), and PD184352 (ERK1/2 inhibitor), we found that both ERK5 and ERK1/2 pathways contribute to the TrkB signaling-induced expression of BDNF mRNA. Pretreating neurons with U0126 decreased the BDNFinduced levels of all measured transcripts. Similar effect was seen for Bix02189, with the exception of exon III transcripts, for which Bix02189 strongly increased both the basal and the induced levels (both to $\sim 30$-fold compared with vehicle-treated neurons not stimulated with BDNF). The robust increase of exon III mRNA levels by the ERK5 inhibitor Bix02189 is possibly accountable to an off-target effect, as similar results were not seen when inhibiting both ERK1/2 and ERK5 with U0126. Similarly to U0126 treatment, PD184352, an ERK1/2-specific inhibitor, caused a statistically significant decrease in the BDNF-induced levels of exon I, II, and IXa transcripts.

Inhibiting PI-3K with Wortmannin decreased the BDNFinduced levels of total BDNF mRNA by $\sim 10 \%$ (Fig. $1 B$ ). At the level of different transcripts, the BDNF-induced expression of exon I-containing transcripts was decreased by $40 \%$ compared with exon I mRNA levels in vehicle-treated neurons stimulated with BDNF (Fig. 1C). Interestingly, Wortmannin increased the basal, but not the BDNF-induced levels of exon III transcripts. The expression of other $B D N F$ transcripts was not affected by inhibiting PI-3K. Together with the results obtained using Bix02189, this indicates that the regulation of exon III transcript basal expression is significantly different from that of other BDNF transcripts.

Applying PKC inhibitor Go6983 to the media did not have significant effect on the TrkB signaling-induced levels of total BDNF mRNA (Fig. 1B). Nevertheless, Go6983 decreased the induction of exon I-containing transcripts by $\sim 50 \%$, but did not have a statistically significant effect on the BDNF-induced levels of other transcripts (Fig. 1C). Notably, Go6983 increased the basal levels of all transcripts except exon III transcripts. However, U73122, a PLC inhibitor, did not have an effect on the expression of any BDNF transcripts neither at $1 \mu \mathrm{M}$ (Fig. $1 C$ ) nor $2.5 \mu \mathrm{M}$ concentration (data not shown). As inhibiting PLC upstream of PKC failed to reproduce the effect of Go6983 on the basal levels of $B D N F$ expression, the upregulation by G06983 can probably be attributed to an off-target effect.

Collectively, rat BDNF expression is strongly induced by applying BDNF to cultured primary neurons, indicating the existence of a positive feedback loop in the regulation of BDNF expression, and this feedback loop is mainly regulated by the activation of MAPK cascades downstream of TrkB receptor.

TrkB signaling-dependent induction of rat BDNF exon I, III, and VI transcripts requires $\mathrm{AP}-1$ proteins

There is evidence that BDNF stimulates AP-1 binding and AP-1dependent transcriptional activity in neurons (Gaiddon et al., 1996; Okamoto et al., 2003). Therefore, we decided to investigate the possible role of AP-1 transcription factors in the regulation of BDNF expression by TrkB signaling. By using RT-qPCR and Western blot analysis, we determined that the expression of mRNA and also protein of all AP-1 members was induced in response to TrkB signaling in our cortical neuron cultures (Fig. 2A,B).

To test whether AP-1 transcription factors play a role in the TrkB signaling-dependent BDNF induction, we used AAVmediated overexpression of FLAG-tagged A-Fos (Fig. $3 A, B$ ), a dominant-negative form of AP-1, consisting of the c-Fos leucine 

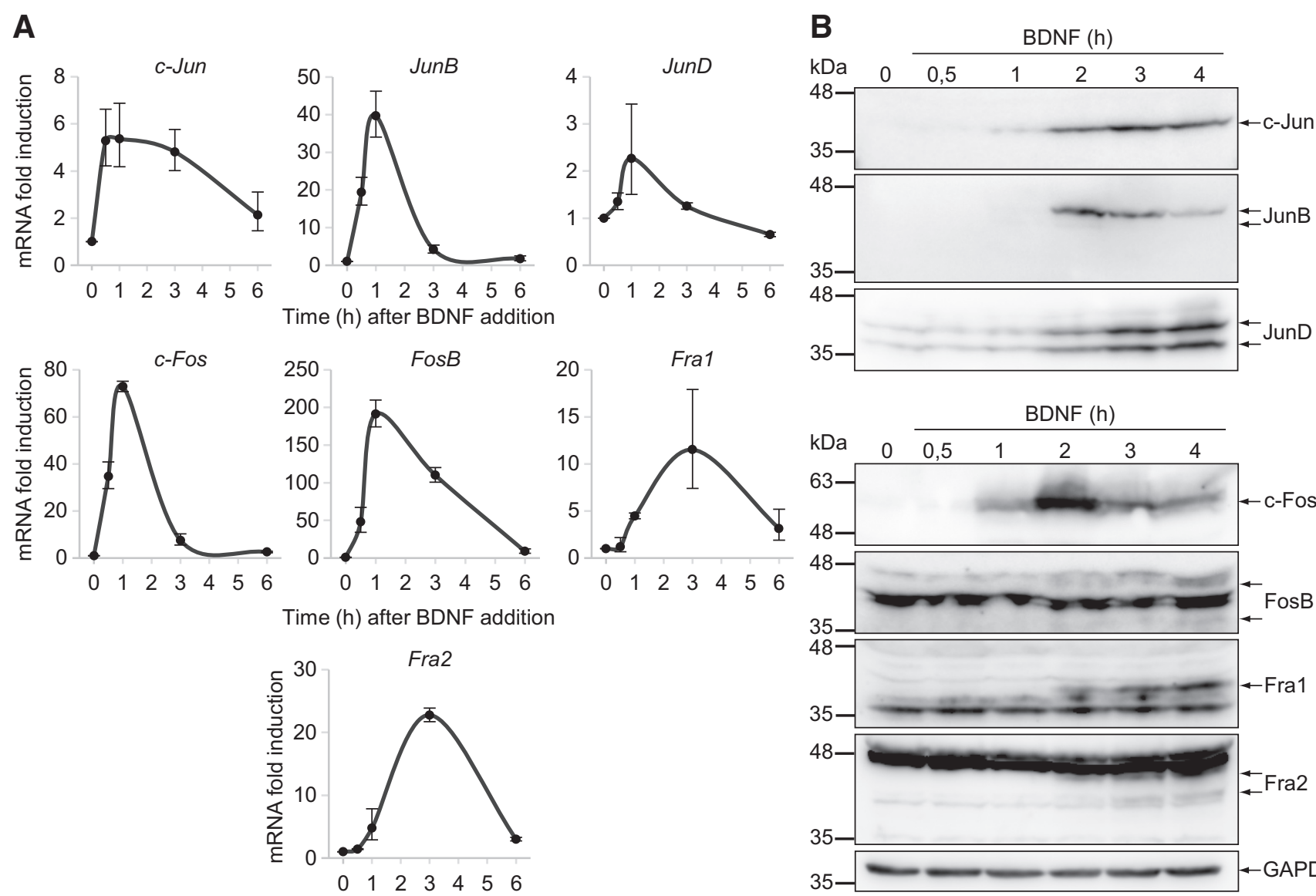

Time (h) after BDNF addition

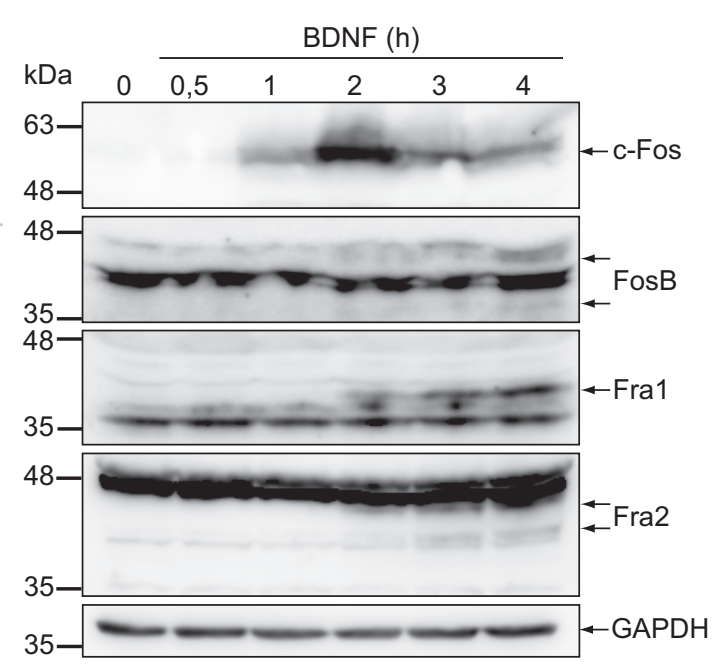

Figure 2. TrkB signaling induces expression of AP-1 family members in rat primary cortical neurons. A, RT-qPCR analysis of AP- 1 family mRNA levels after treating primary neurons with $50 \mathrm{ng} / \mathrm{ml}$ BDNF. mRNA levels are shown as fold induction relative to the levels of the respective transcripts in untreated cells. Error bars represent SEM of three independent experiments. $\boldsymbol{B}$, Western blot analysis of neurons treated with $50 \mathrm{ng} / \mathrm{ml} \mathrm{BDNF}$ for the indicated time at 7 DIV showing that the expression of all the members of the AP- 1 family is induced upon TrkB signaling. Bands corresponding to different AP-1 proteins or GAPDH are shown with arrows.

zipper domain with an acidic amphipathic extension appended to the N-terminus (Olive et al., 1997). Infected neurons were treated with BDNF at 8 DIV for different time periods, and BDNF transcript levels were measured using RT-qPCR. We found that overexpressing A-Fos did not change the basal level of $B D N F$ mRNA expression (Fig. 3C). However, A-Fos overexpression decreased the induced level of total BDNF mRNA by $\sim 30 \%$ at $3 \mathrm{~h}$ of BDNF treatment (from 9.8- to 6.9-fold induction compared with EGFP-expressing neurons not treated with BDNF).

At the level of alternative transcripts, A-Fos overexpression did not change the basal expression of any $B D N F$ transcript, but effectively reduced the BDNF-dependent induction of exon I-containing transcripts by $86 \%$ and $73 \%$ at 3 and $6 \mathrm{~h}$ time point, respectively (Fig. $3 D$ ). However, the induction of exon I transcripts was not completely abolished by the overexpression of A-Fos, with a $\sim 7.6$-fold induction remaining at $3 \mathrm{~h}$ time point compared with untreated neurons overexpressing EGFP. This indicates that the induction of exon I transcripts might also be regulated by other transcription factors in addition to AP-1, or that the remaining induction of exon I transcripts occurs in the minority of cells $(<10 \%)$ that were not infected. A-Fos also diminished the TrkB signaling-dependent induction of exon IIIcontaining transcripts, with the induction being completely abolished at $3 \mathrm{~h}$ time point, and reduced by $36 \%$ at $6 \mathrm{~h}$ treatment with BDNF, and reduced the induced levels of transcript VI by $\sim 18$ and $\sim 40 \%$ at 3 and $6 \mathrm{~h}$ BDNF treatment, respectively. The induction of exon II, IV, and IXa transcripts was not changed by overexpressing A-Fos, indicating that the integrity of TrkB signaling itself was not compromised. Collectively, these results indicate that AP-1 activity is needed for the TrkB signalingdependent transcription of BDNF exon I, III, and VI transcripts, but not for their basal expression.

\section{Induction of $B D N F$ promoter $I$ in response to TrkB signaling} is mediated by $\mathrm{AP}-1$ proteins

As $B D N F$ exon I-containing transcripts showed the strongest induction in response to BDNF treatment, we first decided to elucidate the mechanism behind this induction. For this, we transfected plasmids containing the human or rat $B D N F$ promoter I $(\mathrm{pI})$ regions in front of luciferase coding sequence, together with either A-Fos, or c-Fos and c-Jun overexpression vectors into rat primary neurons. Neurons were treated with BDNF for $8 \mathrm{~h}$ to induce TrkB signaling, after which cells were lysed and luciferase activities were measured. According to our reporter assays, both rat (Fig. $4 A$ ) and human (Fig. 4B) BDNF pI activity were upregulated by BDNF treatment $(\sim 12.2$ - and $\sim 10.9$ fold induction, respectively). Cotransfecting A-Fos together with the reporter constructs effectively decreased the induced levels of promoter activity for both rat and human BDNF $\mathrm{pI}$, by 88 and $83 \%$, respectively. Overexpressing AP-1 proteins c-Jun and c-Fos increased the promoter activity of human and rat $B D N F$ $\mathrm{pI}$ in both unstimulated and BDNF-treated cells (Fig. $4 A, B$ ). 
A

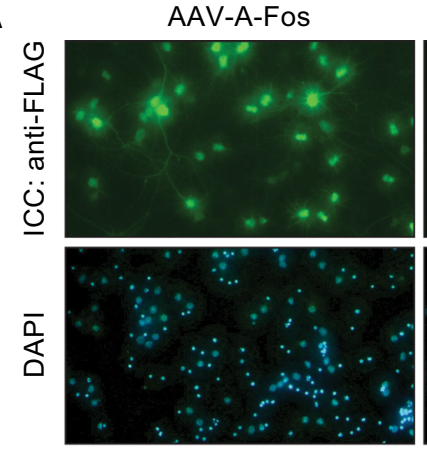

D



$B D N F$ exon IV

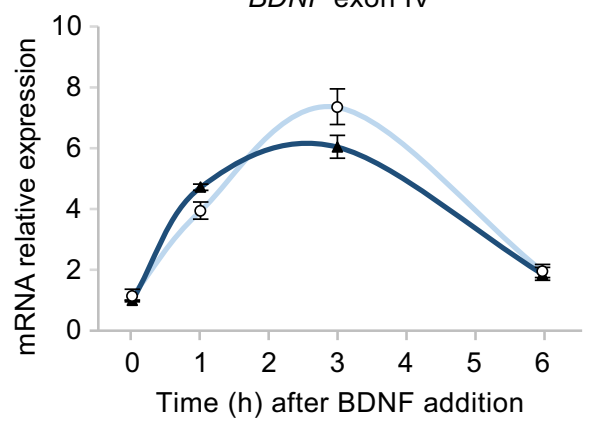

not transduced

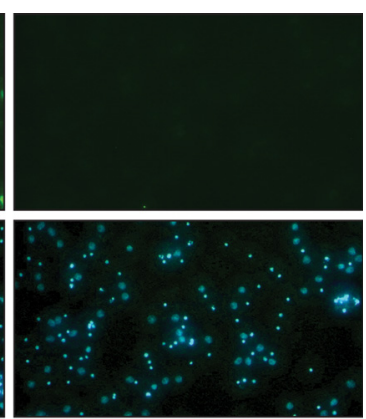

B

WB: anti-FLAG



C

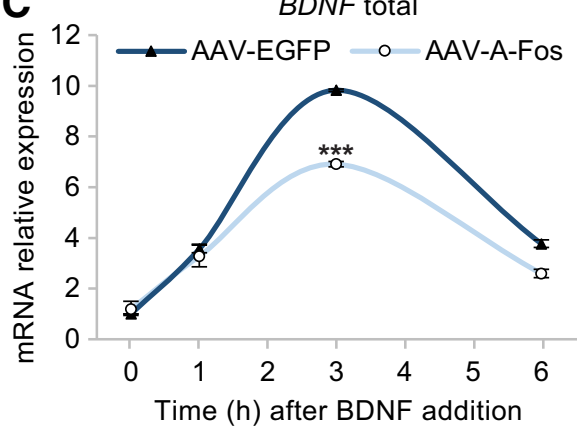

BDNF exon II C
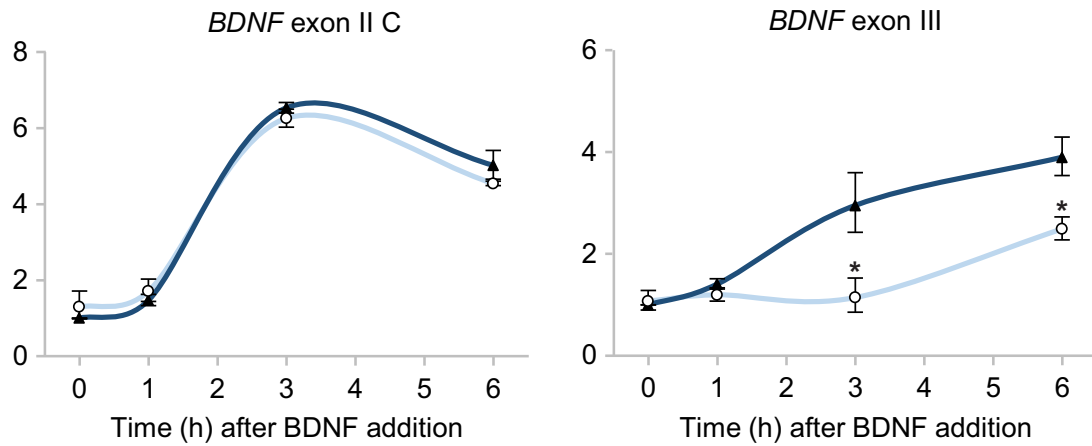

$B D N F$ exon $\mathrm{VI}$

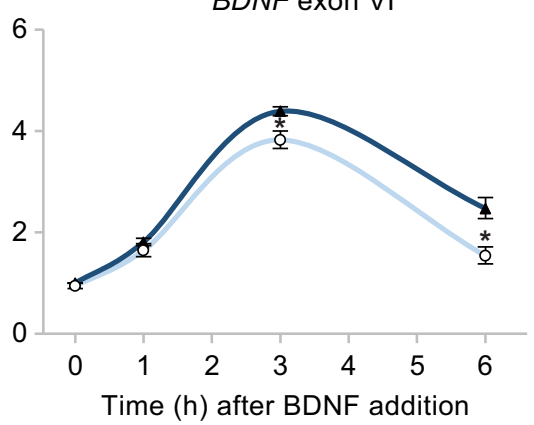



Figure 3. A-Fos, a dominant-negative form of AP-1, interferes with TrkB signaling-dependent induction of BDNF mRNA. $\boldsymbol{A}, \boldsymbol{B}$, Immunocytochemistry (ICC) (A) and Western blot (WB) analysis (B) showing FLAG-tagged A-Fos expression in 8 DIV neurons infected with AAV-A-Fos at 2 DIV.C, D, AP-1 activity is needed for the induction of BDNF mRNA (C) and exon I, III, and VI transcripts (D) upon TrkB signaling. Primary neurons were infected with AAVs encoding either EGFP or A-Fos at 2 DIV and treated with $50 \mathrm{ng} / \mathrm{ml} \mathrm{BDNF}$ at 8 DIV. BDNF transcript levels were measured using RT-qPCR. $\mathrm{mRNA}$ levels are shown relative to the respective transcript levels in untreated neurons transduced with AAV-EGFP. Error bars indicate SEM of at least three independent experiments, and asterisks indicate statistical significance between the respective BDNF transcript levels in AAV-A-Fos and AAV-EGFP transduced neurons at the respective time points. ${ }^{*} p<0.05,{ }^{* *} p<0.01,{ }^{* * *} p<0.001 ; t$ test on log-transformed and autoscaled data.

Next, we checked the effect of overexpressing different combinations of AP-1 transcription factors on human BDNF (hBDNF) pI activity. For that, rat primary neurons were cotransfected with the $\mathrm{h} B D N F \mathrm{pI}$ luciferase construct and combinations of expression constructs encoding different AP-1 factors. The results of the luciferase assay (Fig. $4 C$ ) showed that overexpression of Fos family members alone was not able to elevate the basal or induced levels of $h B D N F \mathrm{pI}$. This is possibly because of the fact that Fos family proteins can only bind DNA when heterodimerized with a member of the Jun family, ATFs, or other possible partner proteins (Eferl and Wagner, 2003). Interestingly, overexpression of FosB reduced the induced levels of $\mathrm{h} B D N F \mathrm{pI}$ upon BDNF treatment. Overexpressing Jun family members alone increased the basal $\mathrm{h} B D N F \mathrm{pI}$ activity $\sim 1.5$ - to 2 -fold, whereas only c-Jun was able to raise the pI-dependent luciferase levels in BDNF-treated cells ( $\sim 2$-fold). In combination with Fos family proteins, Jun family factors were more potent activators of $\mathrm{h} B D N F \mathrm{pI}$ than Jun family members alone. Overexpression of c-Jun together with different Fos family proteins greatly increased the basal activity of pI (from $\sim 7$-fold for Fral, up to $\sim 15$-fold for c-Fos), and also the BDNF-induced pI activity ( $\sim 3$-fold). JunB, on the other hand, was not a potent activator of $\mathrm{h} B D N F \mathrm{pI}$ even together with Fos family proteins: although a modest increase $(\sim 3$ - to 4 -fold $)$ in the basal levels of pI expression was detected, only JunB in combination with c-Fos or Fra2 was able to slightly raise the induced levels of $\mathrm{pI}$ $(\sim 1.7$-fold $)$. Albeit with a less potent activation of $\mathrm{h} B D N F \mathrm{pI}$, overexpressing JunD together with Fos family transcription factors showed similar results as overexpressing c-Jun in combination with Fos family members.

Collectively, these results indicate that both rat and human $B D N F \mathrm{pI}$ are regulated by AP-1 proteins, and different combinations of AP-1 proteins can elicit distinct responses on the activity of $\mathrm{h} B D N F \mathrm{pI}$.

\section{AP-1 proteins regulate human $B D N F$ promoter I activity} through two conserved AP-1 elements

To determine the location of cis-elements necessary for the BDNF-dependent $\mathrm{hBDNF} \mathrm{pI}$ induction, we used deletion mutants of the pI reporter, where the promoter region was shortened 

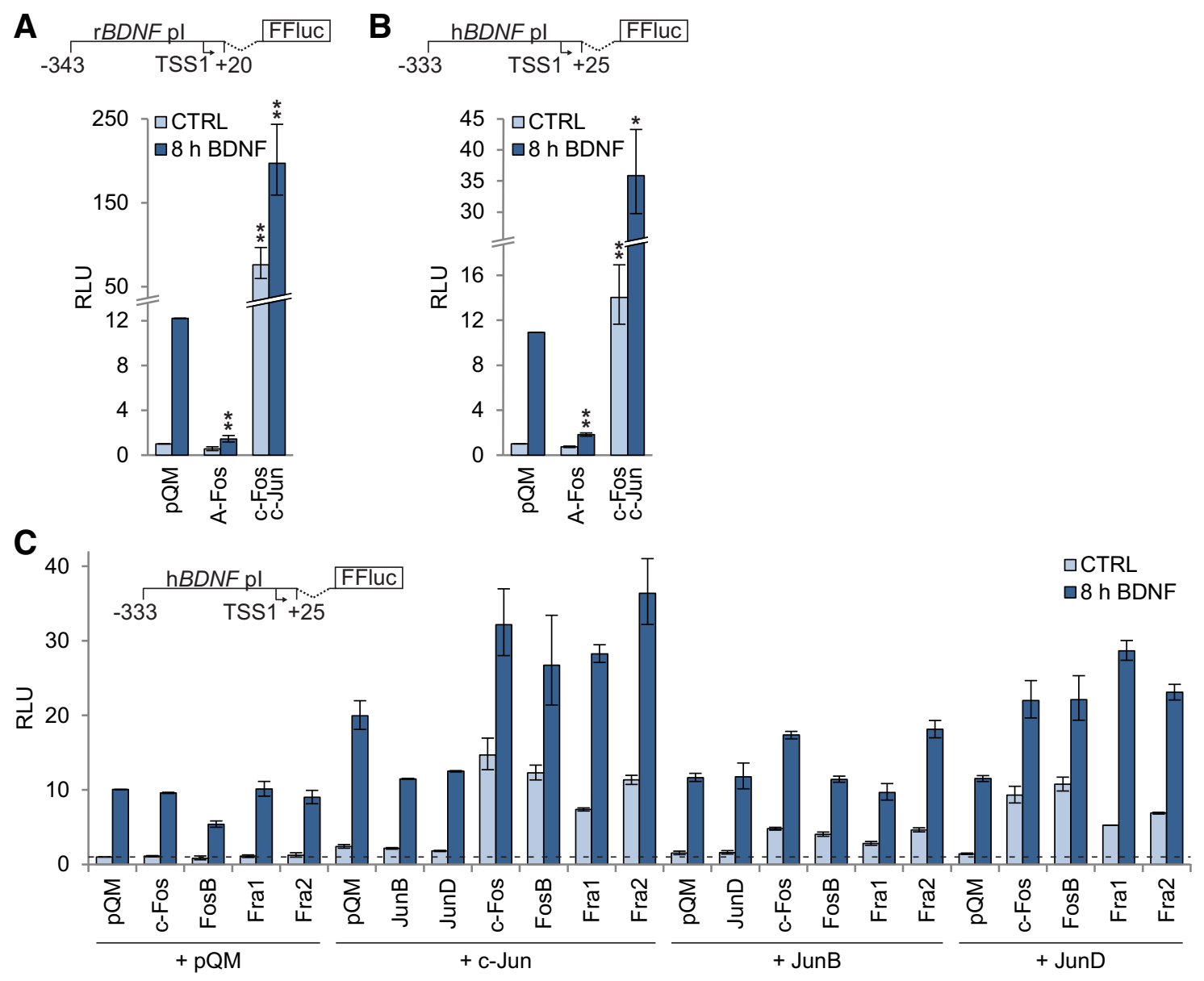

Figure 4. AP-1 proteins mediate BDNF promoter l activity in response to TrkB signaling. $A, B$, AP-1 proteins regulate both rat $(\boldsymbol{A})$ and human $(\boldsymbol{B}) B D N F$ promoter I. At 6 DIV, rat primary neurons were cotransfected with $B D N F$ pl-dependent luciferase reporter constructs (indicated above the graphs) together with constructs coding either A-Fos, or c-Fos, and c-Jun, or empty vector pQM. At $7 \mathrm{DIV}$, neurons were either treated with $50 \mathrm{ng} / \mathrm{ml}$ BDNF for $8 \mathrm{~h}$ or left untreated (CTRL), and luciferase activities were measured. C, AP-1 complex combinations differentially regulate the activity of hBDNF pl. Rat primary neurons were cotransfected with the hBDNF pl construct together with different combinations of vectors encoding AP- 1 proteins or empty vector ( $\mathrm{pQM}$ ) as indicated below the graph. Neurons were left untreated or treated with $50 \mathrm{ng} / \mathrm{ml}$ BDNF for $8 \mathrm{~h}$ at $7 \mathrm{DIV}$, after which luciferase activities were measured. $\boldsymbol{A}$-C, Luciferase activity in untreated cells transfected with pl reporter construct and empty pQM vector was arbitrarily set as 1 ( $\boldsymbol{C}$, dashed line). Numbers next to the schematic figures of promoter constructs indicate distance from the most $5^{\prime}$ transcription start site (TSS1; according to Pruunsild et al., 2007) of rat $(\boldsymbol{A})$ or human $(\boldsymbol{B}, \boldsymbol{C})$ BDNF exon I. Error bars represent SEM from three $(\boldsymbol{A}, \boldsymbol{B})$ or two $(\boldsymbol{C})$ independent experiments. Asterisks indicate statistical significance relative to luciferase activities in cells transfected with pl reporter construct and empty pQM vector that were either left untreated or treated with $B D N F$ for $8 \mathrm{~h}$, respectively $(A, B) .{ }^{*} p<$ $0.05,{ }^{* *} p<0.01,{ }^{* * *} p<0.001 ; t$ test on log-transformed and autoscaled data.

from the $5^{\prime}$ end (pI SphI and pI Eco31 constructs; Fig. 5B). We found that while the region between -333 and -242 was not needed for the BDNF-dependent promoter activation ( $\mathrm{pI}$ SphI construct), removing the region -333 to -166 (pI Eco31 construct) decreased the fold induction by $69 \%$ compared with the pI WT reporter. Additionally, we determined that TrkB signaling also induced the activity of the -166 to +25 region (pI Eco31 construct) by $\sim 4.4$-fold. These results indicate that the cis-elements necessary for the TrkB signaling-dependent activation of $\mathrm{hBDNF} \mathrm{pI}$ are located between -242 and $+25 \mathrm{bp}$ relative to the transcription start site, and that these elements reside both in the -242 to $-166 \mathrm{bp}$ region and the -166 to +25 bp region.

Using bioinformatic analysis of human and rat BDNF pI sequences, we found two putative AP-1 sites (TCACTCA, designated as AP1-1, and TTAGTCA, designated as AP1-2) in BDNF $\mathrm{pI}$ that are conserved between human and rat (Fig. 5A). According to Seldeen et al. (2009), cis-elements differing from the consensus AP-1 element (TGAC/GTCA) by any single nucleotide are capable of binding AP-1 transcription factors. Furthermore, functional AP-1 elements with the core se- quence TTAGTCA have been described in the $S V 40$ promoter (Angel et al., 1987) and in the rat follicle stimulating hormone receptor (FSHR) promoter (Griswold et al., 2001).

To investigate the role of the identified AP1-1 and AP1-2 elements in $\mathrm{h} B D N F$ pI activation in response to TrkB signaling, we used reporter constructs where these putative AP-1 sites were mutated (Fig. 5B). Mutating the AP1-1 site ( $\mathrm{pI}$ AP $1-1 \mathrm{~m}$ construct) decreased hBDNF pI induction upon BDNF treatment from 14.0-fold to 7.6-fold, whereas mutation of the AP1-2 site (pI AP1-2m construct) lowered the induction to 4.1-fold. Mutating both the AP1-1 and the AP1-2 site (pI AP1-1m $2 \mathrm{~m}$ construct) did not further decrease the fold induction compared with mutating only the AP1-2 site. It has been reported that the AP1-1 site overlaps with a functional PasRE cis-element necessary for $\mathrm{hBDNF} \mathrm{pI}$ induction in response to neuronal activity (Pruunsild et al., 2011). Interestingly, mutation of the PasRE (mutation according to Pruunsild et al., 2011) enhanced the induction of hBDNF $\mathrm{pI}$ in response to TrkB signaling by 2.3 -fold, indicating a possible competitive regulation of $\mathrm{pI}$ activity by AP-1 and bHLH-PAS proteins. Together, these results show that the AP1-1 and 


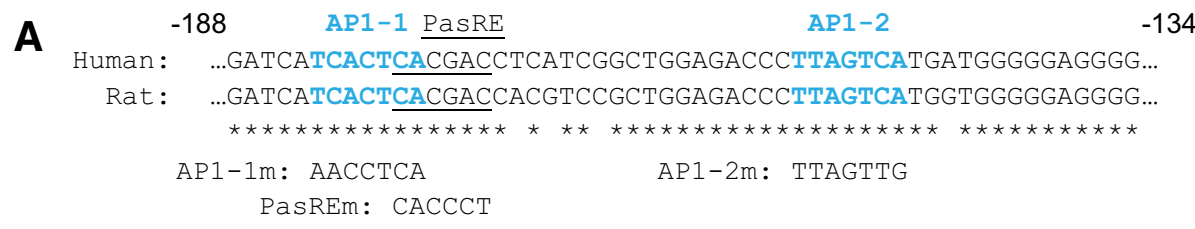

\section{B}
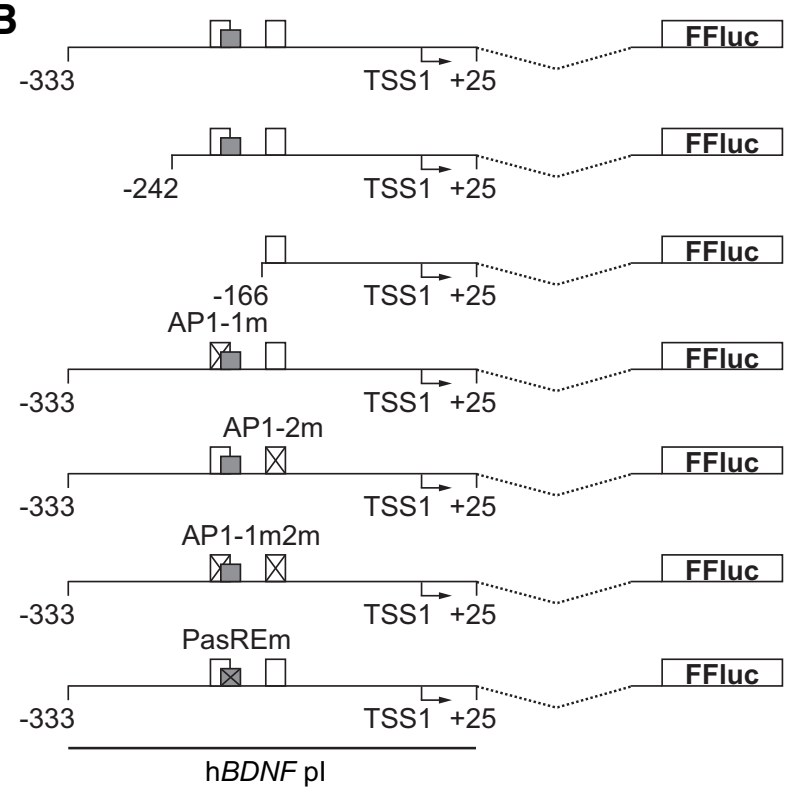

C

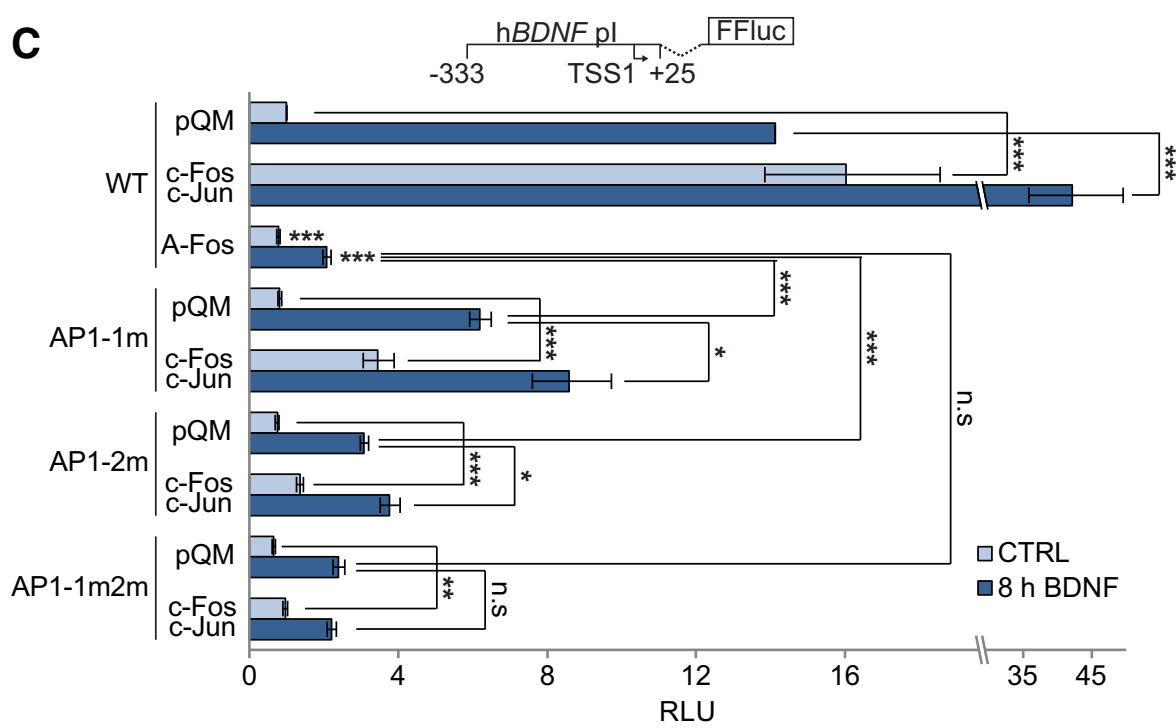

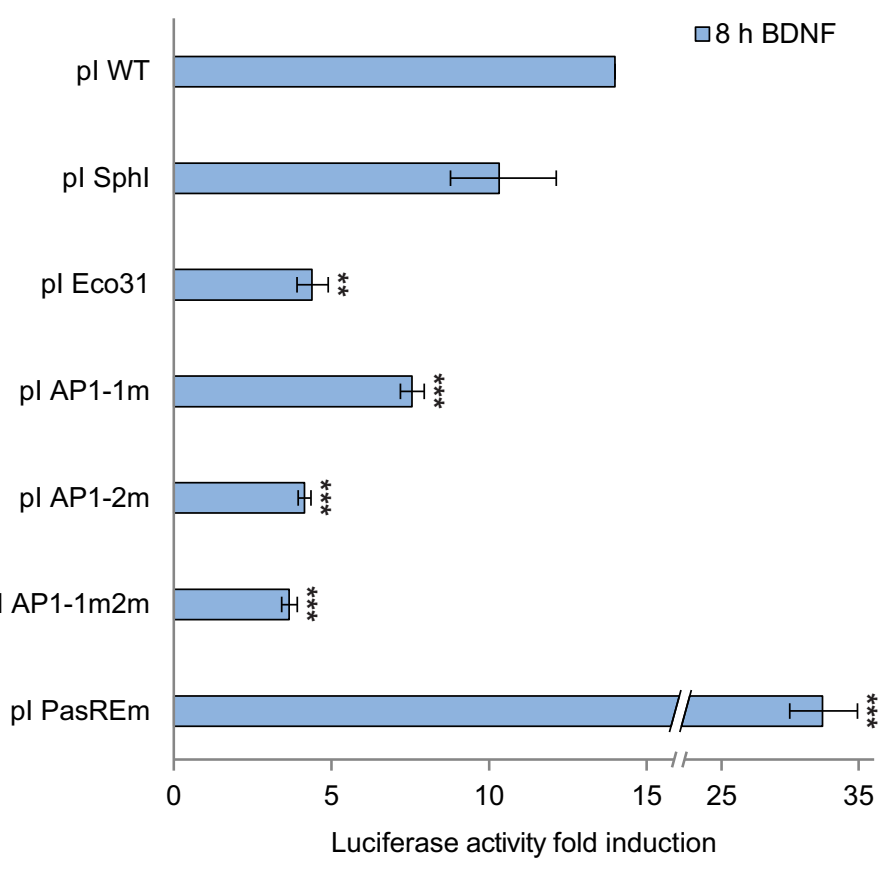

Figure 5. The effect of AP-1 proteins on hBDNF promoter l activity is mediated by two AP-1 cis-elements. A, Alignment of the region in BDNFpl containing two putative AP-1 sites, designated here AP1-1 and AP1-2. The AP-1 sites are shown in blue and bold, the PasRE site overlapping the AP1-1 site is underlined. Mutations used in promoter constructs in this study are shown below the alignment. Numbers next to the alignment or schematic figures of promoter constructs indicate distance from the most 5 ' transcription start site (TSS1; according to Pruunsild et al., 2007) of hBDNF exon I ( $\boldsymbol{A}-\boldsymbol{C})$. B, Schematic representation of the hBDNF pl constructs used in the current study (left), with luciferase signal induction in neurons transfected with the respective promoter constructs in response to BDNF treatment for $8 \mathrm{~h}$ (right). White boxes depict the AP-1 sites; gray boxes represent the PasRE site. C, AP1-1 and AP1-2 sites mediate hBDNFpl response to TrkB signaling. At 6 DIV, neurons were cotransfected with the designated hBDNF pl luciferase reporter constructs together with different expression constructs or empty pQM vector. At $7 \mathrm{DIV}$, neurons were left untreated (CTRL) or treated with $50 \mathrm{ng} / \mathrm{ml} \mathrm{BDNF}$ for $8 \mathrm{~h}$, followed by measurement of luciferase activities. Luciferase activity in untreated cells transfected with the pl WT reporter construct and pQM expression construct was arbitrarily set as 1. Error bars represent SEM of at least three $(\boldsymbol{B})$ or at least five $(\boldsymbol{C})$ independent experiments. Asterisks indicate statistical significance relative to luciferase fold induction in cells transfected with WT promoter construct $(\boldsymbol{B})$, or relative to luciferase activities in cells cotransfected with WT promoter construct and empty pQM vector that were either left untreated or treated with BDNF for $8 \mathrm{~h}$, respectively, or between indicated groups $(\boldsymbol{C}){ }^{*} p<0.05,{ }^{* *} p<0.01,{ }^{* * *} p<0.001 ; t$ test on log-transformed and autoscaled data.

AP1-2 sites are both needed for the induction of $h B D N F$ pI by TrkB signaling, with the AP1-2 site having the predominant role.

As the combination of c-Fos and c-Jun overexpression was one of the most efficient combinations of AP-1 proteins in induc- ing transcription from $\mathrm{h} B D N F \mathrm{pI}$ in both untreated and BDNFtreated neurons (Fig. 4C), we decided to use this combination to investigate the role of the AP1-1 and AP1-2 sites in the regulation of $\mathrm{h} B D N F$ pI by AP-1 proteins. For this, we used the WT hBDNF 
A

pl AP1-1 oligo:

WT: TCCCCATTTGATCATCACTCACGACCTCATCGGCT AP1-1m: TCCCCATTTGATCAAACCTCACGACCTCATCGGCT PasREm: TCCCCATTTGATCATCACTCACCCTCTCATCGGCT

pl AP1-2 oligo:

WT: GCTGGAGACCCTTAGTCATGATGGGGGAGGGGGA AP1-2m: GCTGGAGACCCTTAGTTGTGATGGGGGAGGGGGA

AP1 cons. oligo: CCGCAAGTGACTCAGCGCGGG
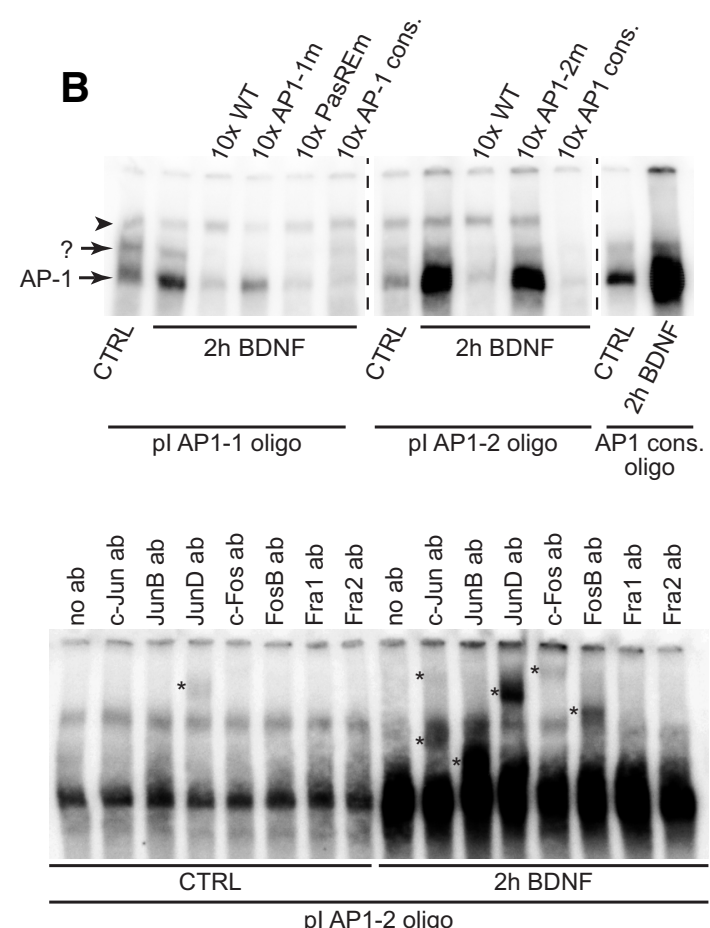

pl AP1-2 oligo

C

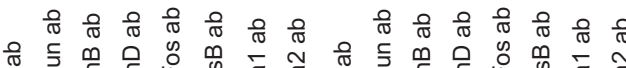
궁 $\frac{\mathrm{AP}_{\mathrm{A}-1 \rightarrow}^{>}}{\mathrm{CTRL}}$ pl AP1-1 oligo

Figure 6. hBDNF promoter I binds AP-1 family members in vitro. A, Oligonucleotides used in EMSA experiments. The sequence of the sense oligo is shown for simplicity; double-stranded oligos were used in all EMSA experiments. The AP-1 sites are shown in blue and bold, the PasRE site is underlined. Mutated nucleotides are shown in red. AP-1 site from the human MT2A promoter was used as an AP-1 consensus oligo. B, EMSA showing AP-1 protein complex binding to hBDNF pl oligos. The probes and lysates used are shown below the panel. CTRL and $2 \mathrm{~h}$ BDNF denote lysates of untreated neurons and lysates of neurons treated with $50 \mathrm{ng} / \mathrm{ml} \mathrm{BDNF}$ for $2 \mathrm{~h}$, respectively. Where indicated above the panel, 10 -fold excess of unlabeled oligo was added to the binding reaction before adding the probe. C, Supershift experiments showing the composition of the AP-1 complex binding to hBDNF pl. Where indicated above the panel, $1 \mu \mathrm{g}$ of the respective antibody (ab) was added to the binding reaction and incubated for $1 \mathrm{~h}$ at room temperature before adding the probe. Supershifted complexes are indicated with asterisks. Probes and lysates used are shown below the panel, as in B. B, C, Arrows show the position of the main AP-1 complex (AP-1), or a complex of unknown composition (denoted with?). Arrowhead indicates unspecific binding. $\boldsymbol{B}, \boldsymbol{C}$, Representative images of three independent experiments. C, Gamma has been altered for clearer visualization of supershifted complexes.

pI promoter construct, or constructs with mutated AP-1 sites, together with overexpression of c-Fos and c-Jun in rat primary neurons (Fig. 5C). Overexpressing c-Fos/c-Jun together with the WT $h B D N F$ pI construct raised both the basal ( $\sim 16$-fold $)$ and the BDNF-induced expression levels ( $\sim 3$-fold) of hBDNF pI (Fig. $5 C)$. Mutating either of the AP1-1 or AP1-2 elements decreased the effect of c-Fos/c-Jun overexpression on $\mathrm{pI}$ activity upon TrkB signaling, but did not completely remove it. When both sites were mutated, the BDNF-induced levels of pI activity were not changed by AP-1 protein overexpression. However, mutating both the AP1-1 and the AP1-2 site did not completely abolish the effect of AP-1 protein overexpression on the basal promoter activity levels, as AP-1 protein overexpression was able to raise the pI AP $1-1 \mathrm{~m} 2 \mathrm{~m}$ reporter activity $\sim 1.5$-fold. Mutating both the AP1-1 and the AP1-2 site together, but not either of the sites alone, decreased the BDNF-induced activity of $\mathrm{pI}$ to the same level as in the case of overexpressing A-Fos together with the WT $\mathrm{h} B D N F$ pI construct $(\sim 2.1$ and $\sim 2.4$-fold induction, respectively, compared with the WT promoter activity in untreated cells cotransfected with empty $\mathrm{PQM}$ vector), indicating that the two AP- 1 sites described in this study are the main cis-acting elements responsible for the AP-1-mediated activation of $\mathrm{hBDNF} \mathrm{pI}$ upon TrkB signaling.

\section{Fos and Jun family proteins bind human $B D N F$ promoter I in vitro}

Next, we decided to investigate whether hBDNF pI is able to bind AP-1 proteins in vitro. For that, we conducted EMSA using oligonucleotides containing either the AP1-1 or the AP1-2 sequence from $\mathrm{h} B D N F \mathrm{pI}$, denoted as pI AP1-1 oligo and pI AP1-2 oligo, respectively (Fig. $6 A$ ). As a positive control, we used an oligo containing the AP- 1 consensus site from the human MT2A promoter (Angel et al., 1987; Lee et al., 1987).

Using lysates from 7 DIV neurons treated with BDNF for $2 \mathrm{~h}$ or left untreated, we found that, whereas the increase in AP-1 binding activity to AP1-1 oligo in response to $2 \mathrm{~h}$ of BDNF treatment remained modest, AP1-2 oligo displayed a substantial induction of AP-1 binding activity upon BDNF treatment, comparable to that of the MT2A promoter oligo with the AP-1 consensus site (Fig. 6B). Using EMSA with excess unlabeled WT oligos or oligos with mutations in the AP1-1, PasRE or AP1-2 sites, we found the major binding complexes (Fig. 6B, arrow with $\mathrm{AP}-1)$ to be specific to both the AP1-1 and the AP1-2 site.

To determine the composition of the AP-1 complex, we preincubated lysates with antibodies against different Jun and Fos family proteins and performed EMSA (Fig. 6C). We detected that with lysates of untreated neurons, both the AP1-1 and the AP1-2 site bound only JunD. As revealed by the formation of supershifted complexes with lysates from neurons treated with BDNF for $2 \mathrm{~h}$, the AP1-1 was bound by c-Jun, JunD, c-Fos, and FosB; and the AP1-2 was bound by c-Jun, JunB, JunD, c-Fos, and FosB. We did not detect binding of Fra1 and Fra2 to either of the pI oligos (Fig. 6C). It is possible that our assay was not sensitive enough to detect JunB supershift using $\mathrm{h} B D N F \mathrm{pI} A P 1-1$ oligo, as the supershifted complex of JunB has similar mobility as another complex seen even without the addition of antibody (Fig. 6C, denoted with?).

When using pI oligos in EMSA, we noticed a complex with slower mobility (Fig. $6 B, C$, denoted with?) than that of the main 

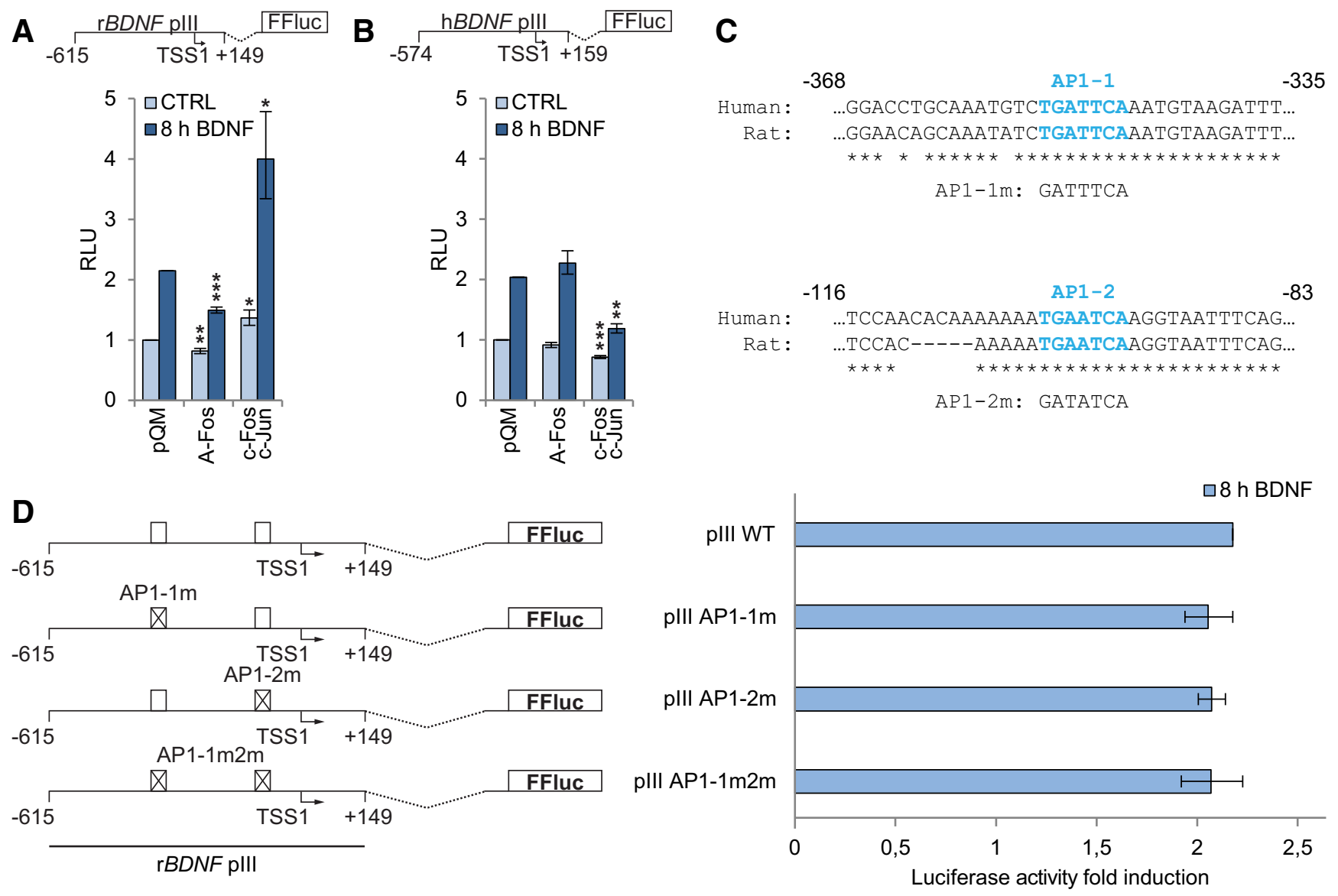

Figure 7. TrkB signaling-dependent induction of rBDNF plll but not of hBDNF plll is positively regulated by AP-1 proteins. $A, B$, At 6 DIV, rat primary neurons were cotransfected with rat ( $A$ ) or human (B) BDNF promoter III-dependent luciferase reporter constructs (indicated above the graphs) together with different expression constructs or empty vector pQM. At 7 DIV, neurons were left untreated (CTRL) or treated with $50 \mathrm{ng} / \mathrm{ml}$ BDNF for $8 \mathrm{~h}$, after which luciferase activities were measured. Luciferase activity in untreated cells cotransfected with pQM was arbitrarily set as 1 . C, Alignment of the regions in BDNF p III containing two putative AP-1 sites, designated AP1-1 and AP1-2. The AP-1 sites are shown in blue and bold. The mutations used in the promoter constructs are shown below the alignment. Numbers next to the alignments or schematic figures of promoter constructs indicate distance from the most 5 ' transcription start site (TSS1; according to Pruunsild et al., 2007) of rat $(\boldsymbol{A}, \boldsymbol{D})$ or human $(\boldsymbol{B}, \boldsymbol{C})$ BDNF exon III. $\boldsymbol{D}$, Schematic representation of the rBDNFplll constructs (left), and luciferase signal induction in neurons transfected with the respective promoter constructs in response to $50 \mathrm{ng} / \mathrm{ml}$ BDNF treatment for $8 \mathrm{~h}$ (right). White boxes depict putative AP-1 elements. Error bars represent SEM from eight $(\boldsymbol{A})$ or five $(\boldsymbol{B}, \boldsymbol{D})$ independent experiments. Asterisks indicate statistical significance relative to luciferase activity in cells transfected with the respective plll luciferase reporter construct and empty pQM vector either left untreated or treated with BDNF, respectively $(\boldsymbol{A}, \boldsymbol{B})$, or relative to luciferase fold induction in cells transfected with WT promoter construct $(\boldsymbol{D}) .{ }^{*} p<0.05,{ }^{* *} p<0.01,{ }^{* * *} p<0.001 ; t$ test on log-transformed and autoscaled data.

AP-1 complex. Furthermore, a complex with similar mobility was also seen when using AP-1 consensus oligo as the probe. Competition with unlabeled oligos indicated that this complex binds to the AP1-2 site, but is not specific for the AP1-1 site (Fig. $6 B)$. Of note, we saw a decrease in binding of this complex in supershift experiments using pI AP1-1 oligo when the untreated neuronal lysate was incubated with c-Jun and JunD antibody, and when lysate from BDNF-treated neurons was incubated with c-Jun antibody (Fig. 6C). Even though according to the competition experiments the complex was not AP1-1-specific, this indicates that Jun family proteins might be involved. When using $\mathrm{pI}$ AP1-2 oligo as the probe, we could not determine a clear pattern in the decrease in binding of the slower-mobility complex in supershift experiments. We propose that the complex consists of Jun family homodimers, Jun family proteins together with ATFs, or other possible Jun heterodimerization partners.

TrkB signaling-dependent induction of rat $B D N F$ promoter III but not human $B D N F$ promoter III is positively regulated by AP-1 proteins

As abolishing AP-1 activity reduced the induction of $\mathrm{r} B D N F$ exon III transcripts upon TrkB signaling (Fig. 3D), we decided to study whether the exon III proximal promoter region contains the necessary elements for TrkB signaling-dependent induction. For that, we cloned both the rat and human BDNF promoter III (pIII) regions upstream of luciferase reporter gene, and transfected these constructs into rat primary neurons together with plasmids encoding different effector proteins. Neurons were then treated with BDNF and luciferase activities were measured.

Our results showed that both rat BDNF pIII (Fig. 7A) and human $B D N F$ pIII (Fig. $7 B$ ) were induced $\sim 2$-fold upon TrkB signaling. Overexpressing A-Fos decreased both the basal and the BDNFinduced activity of rat BDNF (rBDNF) pIII, by 18 and 30\%, respectively, indicating that AP-1 activity is involved in the induction of rBDNF pIII. Moreover, overexpressing c-Fos and c-Jun increased both the basal and the induced levels of $\mathrm{r} B D N F$ pIII, by 36 and $86 \%$, respectively (Fig. $7 A$ ). In contrast, the activity of human $B D N F$ ( $\mathrm{h} B D N F)$ pIII was not affected by A-Fos, and overexpressing c-Fos and $\mathrm{c}$-Jun rather decreased the activity of the promoter, suggesting that AP-1 proteins do not participate in the TrkB signalingdependent regulation of $\mathrm{h} B D N F$ pIII (Fig. $7 B$ ).

Using bioinformatic analysis, we identified two putative AP-1 elements in the rat BDNF pIII region, that we named AP1-1 and 


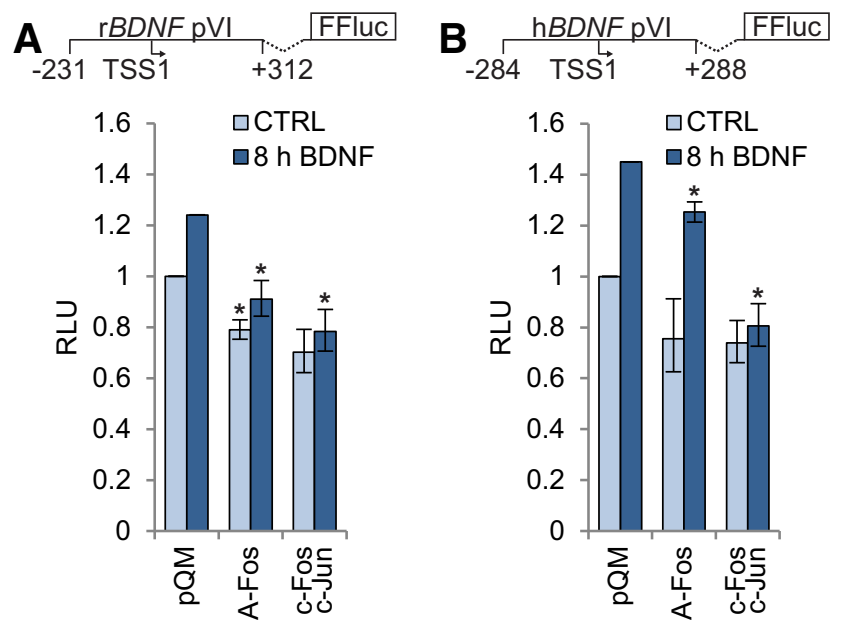

Figure 8. AP-1 activity is needed for the induction of both rat and human BDNF pVI in response to TrkB signaling. $A, B, A t 6$ DIV, rat primary neurons were cotransfected with either rat $(\boldsymbol{A})$ or human $(\boldsymbol{B})$ BDNF promoter VI-dependent luciferase reporter constructs, together with different expression constructs or empty pQM vector. At 7 DIV, neurons were left untreated (CTRL) or treated with $50 \mathrm{ng} / \mathrm{ml}$ BDNF for $8 \mathrm{~h}$, followed by measuring luciferase activities. Luciferase activity in untreated cells cotransfected with $\mathrm{PQM}$ was set as 1 . Numbers next to the schematic figures of promoter constructs indicate distance from the most $5^{\prime}$ transcription start site (TSS1; according to Pruunsild et al., 2007) of rat ( $\boldsymbol{A}$ ) or human (B) BDNF exon VI. Error bars represent SEM from four $(\boldsymbol{A})$ or three $(\boldsymbol{B})$ independent experiments. Statistical significance is relative to luciferase activity in cells transfected with the respective $\mathrm{pVI}$ reporter construct and empty $\mathrm{pQM}$ vector left either untreated or treated with BDNF for $8 \mathrm{~h}$, respectively. ${ }^{*} p<0.05$, ${ }^{* *} p<0.01,{ }^{* * *} p<0.001 ; t$ test on log-transformed and autoscaled data.

AP1-2 (Fig. 7C). Of note, both of these sites are conserved between human and rat. To check whether these AP-1 elements are responsible for the TrkB signaling-dependent induction of rBDNF pIII, we used luciferase reporter constructs where these sites alone (pIII AP1-1m and pIII AP1-2m constructs) or together ( $\mathrm{pIII}$ AP1-1m2m construct) were mutated (Fig. 7D). Using reporter assay, we found that neither mutating these sites alone nor in combination had effect on the induction of $\mathrm{r} B D N F$ pIII in response to TrkB signaling (Fig. 7D).

Together, these results indicate that rat and human BDNF pIII are differentially regulated in response to TrkB signaling, and that $\mathrm{r} B D N F$ pIII does not seem to contain functional AP-1 sites, suggesting that the effect of $\mathrm{AP}-1$ proteins on $\mathrm{r} B D N F$ pIII activity is indirect.

\section{Induction of $B D N F$ promoter VI in response to TrkB signaling needs AP-1 activity}

To elucidate the mechanism behind the TrkB signaling-induced expression of BDNF exon VI transcripts, we cloned the rat and human $B D N F$ promoter VI ( $\mathrm{pVI}$ ) regions into luciferase reporter plasmid and transfected them into rat primary neurons together with either A-Fos, or c-Fos and c-Jun coding plasmids, treated the cells with BDNF and measured luciferase activity (Fig. 8A,B). The activities of $\mathrm{r} B D N F \mathrm{pVI}$ and $\mathrm{h} B D N F$ pVI were only slighty induced, 1.2- and 1.4-fold, respectively, upon TrkB signaling. Overexpressing A-Fos together with $\mathrm{r} B D N F$ pVI reporter construct decreased both the basal and the induced activity of the promoter, by 21 and 26\%, respectively. However, overexpressing c-Jun and c-Fos also reduced the promoter activity, by 30 and $37 \%$ for the basal and the induced levels, respectively. Comparable effects were seen for $\mathrm{h} B D N F \mathrm{pVI}$, indicating that the regulation of both rat and human BDNF pVI is similar. Bioinformatic analysis failed to find AP-1 cis-elements conserved between rat
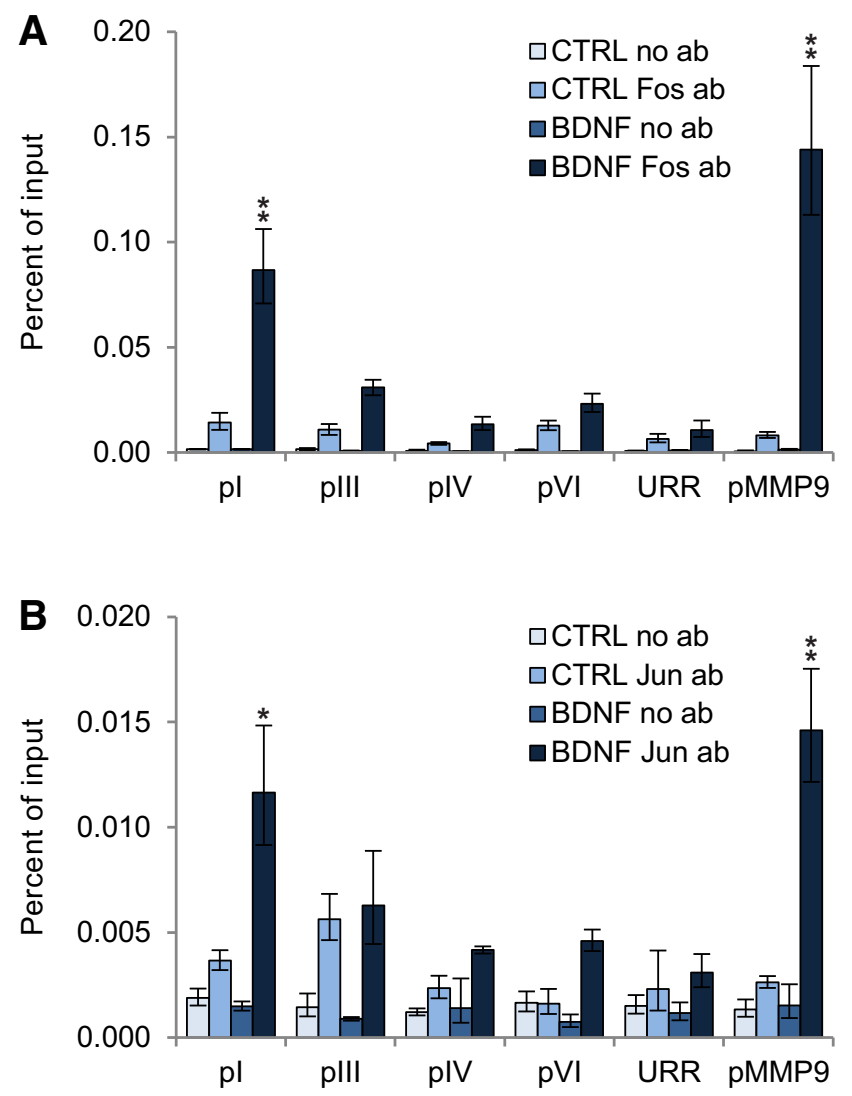

Figure 9. AP-1 proteins bind to endogenous $r B D N F$ pl in rat primary neurons upon TrkB signaling. At 7 DIV, rat primary neurons were either left untreated (CTRL) or treated with 50 $\mathrm{ng} / \mathrm{ml}$ BDNF for $2 \mathrm{~h}$ (BDNF). ChIP analysis was performed using either pan-Fos antibody (ab) (A) or $\boldsymbol{c}$-Jun $a b(\boldsymbol{B})$, together with no ab control in immunoprecipitation. DNA quantity of the respective regions was measured using $\mathrm{QPCR}$. Data are shown as a fraction of immunoprecipitated DNA to total DNA quantity of the respective region (percent of input). pl, pIII, pIV, and pVI denote the respective rBDNF promoter regions. The MMP9 promoter region (pMMP9) was used as a positive control, an unrelated region in chromosome 1 (URR) was used as a negative control. Statistical significance is relative to the respective group's binding to URR. ${ }^{*} p<0.05,{ }^{* *} p<$ $0.01,{ }^{* * *} p<0.001 ; t$ test on log-transformed data.

and human in BDNF pVI, suggesting that the effect of AP-1 proteins on BDNF pVI activity is indirect.

\section{AP-1 proteins bind endogenous $B D N F$ promoter $I$ in rat primary neurons upon TrkB signaling}

Next, we analyzed how the binding of AP-1 proteins to different $\mathrm{r} B D N F$ promoter regions changed in response to TrkB signaling in primary neurons. For this, we treated primary neurons with BDNF for $2 \mathrm{~h}$ at 7 DIV, and performed ChIP analysis using panFos and c-Jun antibodies. The MMP9 promoter region, which has previously been shown to bind c-Fos in primary neurons in response to TrkB signaling (Kuzniewska et al., 2013), was used as a positive control. As transduction with AAV-A-Fos did not change the inducibility of $\mathrm{r} B D N F$ exon IV-containing transcripts in response to TrkB signaling (Fig. $3 C$ ), we used the $\mathrm{r} B D N F$ promoter IV region as an internal negative control for ChIP analysis.

Our results showed that in unstimulated neurons, neither Fos family proteins (Fig. 9A) nor c-Jun (Fig. 9B) bound to rBDNF promoters I, III, IV, and VI. This is in accordance with the fact that the basal expression and DNA binding activity of Fos family proteins and c-Jun is very low in unstimulated neurons (Figs. 2B, $6 C)$. However, when the cells were treated with BDNF for $2 \mathrm{~h}$, binding of the Fos family members and c-Jun was detected at the 

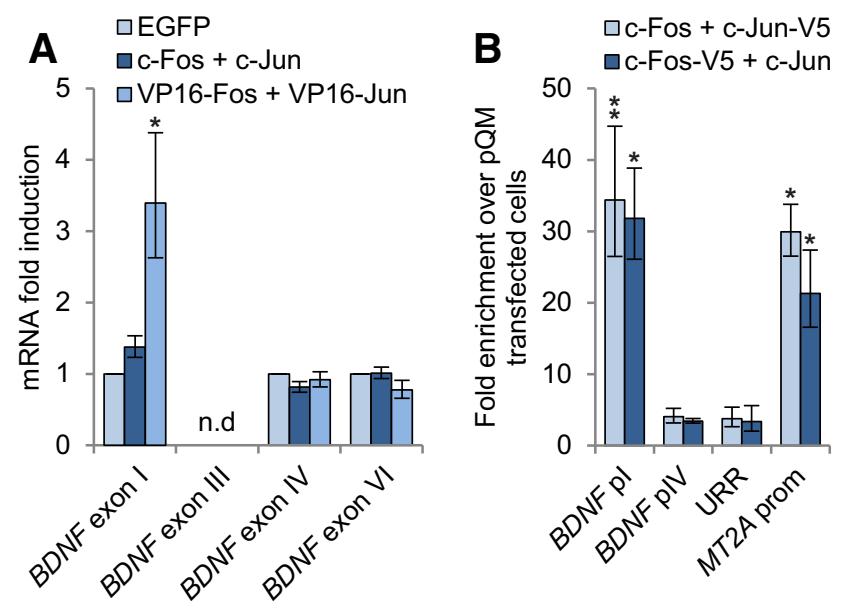

Figure 10. AP-1 proteins regulate the levels of $h B D N F$ exon I transcripts and bind $h B D N F p l$ in HEK293 cells. $A, \mathrm{RT}-\mathrm{qPCR}$ analysis of different $\mathrm{h} B D N$ F transcripts in HEK293 cells transfected with either EGFP coding vector, $c-$ Fos and c-Jun overexpression constructs, or the respective AP-1 VP16-fusion protein overexpression constructs. The expression of hBDNF exon III transcripts could not be detected (n.d., Not detectable). mRNA expression is shown relative to the expression levels of the respective transcripts in EGFP overexpressing cells. $\boldsymbol{B}$, ChIP analysis showing binding of AP-1 proteins to endogenous $\mathrm{hBDNF}$ pl in cells overexpressing V5-tagged c-Fos and c-Jun proteins. HEK293 cells were transfected with combination of V5-tagged Fos and Jun expression constructs or empty $\mathrm{pQM}$ vector. Immunoprecipitation was performed using anti-V5 agarose. Binding of overexpressed Fos-V5 and Jun-V5 to hBDNF pl and plV was measured using $\mathrm{qPCR}$, the human MT2A promoter (MT2A prom) region and an unrelated region in chromosome 11 (URR) were used as positive and negative controls, respectively. Data are shown as fold enrichment of immunoprecipitated DNA normalized to input relative to the respective DNA levels in cells transfected with empty PQM vector. Error bars represent SEM of at least three independent experiments $(\boldsymbol{A}, \boldsymbol{B})$. Statistical significance is relative to the respective transcript levels in EGFP transfected cells $(\boldsymbol{A})$, or relative to the respective fold enrichment of binding at URR $(\boldsymbol{B}) .{ }^{*} p<0.05,{ }^{* *} p<0.01,{ }^{* * *} p<0.001 ; t$ test on log-transformed $(\boldsymbol{A})$, and on logtransformed and autoscaled data $(\boldsymbol{B})$.

rBDNF $\mathrm{pI}$ region (Fig. 9). The extent of this binding was comparable to that of the MMP9 promoter region used as a positive control. No significant binding of AP-1 proteins was seen for rBDNF promoters III, IV, and VI.

Collectively, these results indicate that AP-1 proteins directly regulate the activity of $\mathrm{r} B D N F \mathrm{pI}$, whereas the effect of AP-1 proteins on $\mathrm{r} B D N F$ pIII and pVI activity is indirect, possibly acting through different transcription factors that are induced by AP-1 proteins.

\section{AP-1 proteins upregulate human $B D N F$ exon I but not exon III or exon VI transcripts in HEK293 cells}

To assess, whether AP-1 proteins regulate $\mathrm{h} B D N F$ transcription in the endogenous context, we overexpressed c-Fos and c-Jun, or their constitutively active VP16-fusion counterparts in HEK293 cells and measured the expression of different $\mathrm{h} B D N F$ transcripts using RT-qPCR (Fig. 10A). Whereas overexpressing c-Fos and $\mathrm{c}$-Jun did not significantly increase the expression of $\mathrm{h} B D N F$ transcripts, VP16-Fos and VP16-Jun induced the expression of $\mathrm{h} B D N F$ exon I-containing transcripts $\sim 3$.4-fold, indicating that AP-1 proteins are able to upregulate the expression of endogenous $\mathrm{h} B D N F$ exon I transcripts. mRNA levels of exon IV and exon VI transcripts were not changed in response to overexpressing AP-1 proteins or their VP16-chimeric counterparts. The expression of $\mathrm{h} B D N F$ exon III transcripts was not detectable in HEK293 cells.

Next, we investigated whether AP-1 proteins bind endogenous $\mathrm{h} B D N F \mathrm{pI}$ using ChIP assay in HEK293 cells overexpressing
V5-tagged AP-1 proteins (Fig. 10B). We found that the overexpressed AP-1 proteins bound the $\mathrm{h} B D N F \mathrm{pI}$ region and the $M T 2 A$ promoter, used as a positive control, but not the $\mathrm{h} B D N F$ pIV region, which was used as a negative control. As AP-1 proteins did not regulate the expression of $\mathrm{h} B D N F$ exon III and exon VI transcripts, we did not check AP-1 binding to these promoters. Together, our results indicate that the expression of endogenous $\mathrm{h} B D N F$ exon I transcripts can be directly regulated by $\mathrm{AP}-1$ proteins.

\section{Discussion}

The role of BDNF as an autocrine or paracrine survival factor has been well established (Miranda et al., 1993; Ghosh et al., 1994; Acheson et al., 1995; Davies and Wright, 1995; Hansen et al., 2001; Jiang et al., 2005; Kuribara et al., 2011; Wang et al., 2015). Autocrine functions of BDNF have also been implicated in axon development (Cheng et al., 2011) and dendritogenesis (Wirth et al., 2003). Here, we show that the expression of BDNF mRNA is extensively upregulated by TrkB signaling. We propose that this positive feedback loop is important in providing sufficient levels of BDNF in the aforementioned processes. Furthermore, as TrkB signaling can induce BDNF secretion (Krüttgen et al., 1998), the positive feedback mechanism of $B D N F$ expression described in the current study could result in a local self-amplifying autocrine loop.

Autocrine activation of BDNF-TrkB axis is also associated with an unfavorable outcome in neuroblastomas, with TrkB signaling stimulating both growth and survival of tumor cells (Ho et al., 2002; Girgert et al., 2003). Although it has not been shown that the activation of TrkB induces $B D N F$ transcription in neuroblastomas, it is plausible that such positive feedback loop exists and contributes to the survival of tumor cells. Furthermore, dysregulation of BDNF expression is associated with the pathophysiology of various psychiatric disorders (Autry and Monteggia, 2012). Therefore, elucidating the mechanism behind BDNF autoregulation could lead to better therapeutic means for both treating cancer and psychiatric disorders where the regulation of BDNF expression is defective.

So far, two studies have assessed the BDNF-TrkB-induced positive feedback loop in $B D N F$ transcriptional regulation in primary cortical neurons, focusing on the regulation of exon IV transcripts (Yasuda et al., 2007; Zheng and Wang, 2009). The study by Yasuda et al. (2007) showed that BDNF exon IV transcripts are upregulated in response to TrkB activation by BDNF in cultured rat primary cortical neurons. However, the regulation of other $B D N F$ transcripts was not studied. Similar observation about the induction of BDNF exon IV transcripts was made by Zheng and Wang (2009). In their study, the effect of BDNF treatment on the induction of $B D N F$ exon I, II, and VI transcripts was addressed in addition to exon IV transcripts, and it was found that the levels of these transcripts are not induced in response to TrkB signaling. In the present study, we show that not only the expression of exon IV transcripts, but also of exon I, II, III, VI, and IXa transcripts is upregulated by TrkB signaling in primary neurons, with the fastest induction for exon IV and exon IXa transcripts, and the strongest induction for exon I transcripts, indicating that different $B D N F$ promoters are used to control the exact temporal pattern of total BDNF mRNA expression after TrkB activation. It should be noted that in the study by Zheng and Wang (2009), BDNF transcript levels were measured only at $1 \mathrm{~h}$ after TrkB activation. Thus, their results are in accord with our study, because we show that the expression of exon I, II, and VI transcripts was not significantly induced after $1 \mathrm{~h}$ of BDNF treat- 
ment, whereas exon IV transcripts displayed a moderate $\sim 8$-fold induction. Furthermore, we show that at later time points the levels of exon I, II, and VI transcripts are also increased in response to TrkB signaling. As it has been reported that the expression of BDNF exon IV transcripts can be induced as an immediate-early gene in response to neuronal activity (Lauterborn et al., 1996; Tao et al., 1998), it is possible that the fast induction of exon IV and IXa transcripts upon TrkB signaling could be independent of protein synthesis. It is plausible that in vivo, the BDNF transcripts that are induced first in response to TrkB signaling provide enough BDNF to start and sustain the BDNF autocrine loop, which in turn would induce the expression of other, more slowly inducible BDNF transcripts (eg, exon I, II, III transcripts), further prolonging the TrkB signaling necessary for various physiological outcomes.

The effect of TrkB signaling on the regulation of BDNF transcription has also been shown in vivo: infusion of BDNF into the dentate gyrus of adult anesthetized rats triggers stable LTP, an activity-dependent synaptic plasticity, and upregulates both $B D N F$ exon IV-containing transcripts and total BDNF mRNA levels (Wibrand et al., 2006). Furthermore, it has been reported that $\mathrm{C} / \mathrm{EBP} \beta$-mediated $\mathrm{BDNF}$-positive feedback loop regulating $B D N F$ exon IV mRNA expression in the hippocampus is important for memory consolidation in vivo (Bambah-Mukku et al., 2014), indicating that BDNF autoregulation is critical for hippocampus-dependent memory functions. We propose, in the light of our results obtained using primary cortical neuron cultures, that not only the induction of exon IV transcripts, but also of other BDNF transcripts could be important for memoryrelated functions. Moreover, our results suggest that in addition to the role of BDNF-positive feedback loop in the hippocampus, such regulatory mechanisms might be involved in proper functioning and/or development of the cortex.

It is well proven that BDNF potentiates synaptic transmission that is connected to neuronal membrane depolarization ( $\mathrm{Lu}$, 2003; Park and Poo, 2013). As the expression of BDNF is also activated by membrane depolarization and calcium influx into neurons (Park and Poo, 2013), one might argue that the effects seen in this study are a result of increased synaptic activity, and not caused by direct regulation of BDNF gene expression by TrkB signaling. However, it has been reported that TrkB signaling but not neuronal activity activates ERK5 pathway in neurons (Cavanaugh et al., 2001). By using pharmacological inhibitors, we show that the BDNF-positive feedback loop in primary cortical neurons is conveyed through both ERK1/2 and ERK5 pathways, suggesting that the induction of $B D N F$ is at least partially conveyed through different pathways upon TrkB signaling and neuronal activity. Furthermore, it has been described that upon neuronal activity, $\mathrm{hBDNF} \mathrm{pI}$ is activated by the depolarizationinduced NPAS4 transcription factor through a conserved PasRE element in BDNF pI (Pruunsild et al., 2011). Here, we show that this PasRE element is not involved in the TrkB signalingmediated activation of $\mathrm{h} B D N F \mathrm{pI}$. Moreover, it has been reported that in primary culture of cortical neurons, synapses are not yet functional at 7 DIV (Basarsky et al., 1994; Chiappalone et al., 2006; Cohen et al., 2008). Therefore, it is highly unlikely that the induction of BDNF in response to TrkB signaling in our study was due to an increase in neuronal activity.

Although the cis-elements responsible for the neuronal depolarization-dependent $B D N F$ transcription have been widely studied (West et al., 2001; Greer and Greenberg, 2008; Pruunsild et al., 2011), the cis-elements and trans-acting factors regulating $B D N F$ expression in response to TrkB signaling have been poorly characterized. Here, we show that AP-1 family transcription factors are necessary for the upregulation of BDNF exon I, III, and VI transcripts in response to TrkB signaling. Moreover, we have identified two functional AP-1 cis-elements in $\mathrm{hBDNF} \mathrm{pI}$, that are conserved between human and rat. Importantly, we have previously shown that the AP1-1 cis-element in $\mathrm{hBDNF}$ pI is not necessary for $\mathrm{h} B D N F$ pI activation in response to depolarization (Pruunsild et al., 2011). Here, we show that the AP1-1 element mediates TrkB signaling-dependent activation of $h B D N F$ pI. Furthermore, as stated previously, the neuronal activity-responsive PasRE element in hBDNF pI (Pruunsild et al., 2011) does not contribute to the BDNF-dependent promoter activation. Rather, mutating the PasRE site increased the promoter's inducibility in response to TrkB signaling, possibly indicating complex interplay and competitive inhibition between TrkB signaling and neuronal activity-dependent induction of $\mathrm{h} B D N F$ pI. Together, these results indicate that the regulation of $B D N F$ expression by neuronal activity and TrkB signaling can be conveyed through different cis-elements and trans-acting factors, further adding complexity to the elaborate regulation of BDNF gene expression.

AP-1 transcription factors have been implicated in the regulation of $B D N F$ transcription by other groups. Compared with wild-type mice, the induction of BDNF in response to kainateevoked neuronal activity was reduced in the hippocampi of postnatal forebrain neuron conditional c-Fos knock-out mice both at mRNA (Dong et al., 2006) and protein levels (Zhang et al., 2002). No change in basal BDNF levels was seen in those knock-out mice (Zhang et al., 2002). It is plausible that the lower BDNF inducibility by kainate treatment seen in the $c$-Fos knock-out mice is due to faulty BDNF autoregulation, since our results indicate that AP-1 activity is needed for the TrkB signaling-dependent induction of BDNF exon I, III, and VI transcripts. The dysregulation of BDNF expression in the c-Fos knock-out mice could partially be caused by subeffective use of the two novel AP-1 sites in BDNF pI identified in our study. Moreover, in agreement with our results, overexpressing constitutively active c-Fos in cultured hippocampal neurons increases BDNF mRNA levels (Benito et al., 2011), further indicating that $\mathrm{AP}-1$ proteins are involved in the regulation of $B D N F$ expression.

In conclusion, we have shown that in primary cultured cortical neurons, the BDNF gene is a subject to an extensive autoregulatory-positive feedback loop, where TrkB signaling induces the expression of all major BDNF transcripts. Elucidating the mechanism behind this phenomenon, we found that the upregulation of exon I, III, and VI transcripts is dependent on AP-1 family transcription factors, with a direct effect on BDNF promoter I and an indirect effect on promoters III and VI. Finally, we have identified two conserved functional AP-1 sites in the BDNF promoter I region necessary for the induction of exon I transcripts in response to TrkB signaling. This novel knowledge of BDNF autoregulation and its mechanisms provides new insights into the complex regulation of BDNF gene expression.

\section{References}

Acheson A, Conover JC, Fandl JP, DeChiara TM, Russell M, Thadani A, Squinto SP, Yancopoulos GD, Lindsay RM (1995) A BDNF autocrine loop in adult sensory neurons prevents cell death. Nature 374:450-453. CrossRef Medline

Aid T, Kazantseva A, Piirsoo M, Palm K, Timmusk T (2007) Mouse and rat BDNF gene structure and expression revisited. J Neurosci Res 85: 525-535. CrossRef Medline

Alberini CM (2009) Transcription factors in long-term memory and synaptic plasticity. Physiol Rev 89:121-145. CrossRef Medline

Angel P, Imagawa M, Chiu R, Stein B, Imbra RJ, Rahmsdorf HJ, Jonat C, 
Herrlich P, Karin M (1987) Phorbol ester-inducible genes contain a common cis element recognized by a TPA-modulated trans-acting factor. Cell 49:729-739. CrossRef Medline

Autry AE, Monteggia LM (2012) Brain-derived neurotrophic factor and neuropsychiatric disorders. Pharmacol Rev 64:238-258. CrossRef Medline

Baj G, Del Turco D, Schlaudraff J, Torelli L, Deller T, Tongiorgi E (2013) Regulation of the spatial code for BDNF mRNA isoforms in the rat hippocampus following pilocarpine-treatment: a systematic analysis using laser microdissection and quantitative real-time PCR. Hippocampus 23: 413-423. CrossRef Medline

Bambah-Mukku D, Travaglia A, Chen DY, Pollonini G, Alberini CM (2014) A positive autoregulatory BDNF feedback loop via C/EBP $\beta$ mediates hippocampal memory consolidation. J Neurosci 34:12547-12559. CrossRef Medline

Basarsky TA, Parpura V, Haydon PG (1994) Hippocampal synaptogenesis in cell culture: developmental time course of synapse formation, calcium influx, and synaptic protein distribution. J Neurosci 14:6402-6411. Medline

Benito E, Valor LM, Jimenez-Minchan M, Huber W, Barco A (2011) cAMP response element-binding protein is a primary hub of activity-driven neuronal gene expression. J Neurosci 31:18237-18250. CrossRef Medline

Bibel M, Barde YA (2000) Neurotrophins: key regulators of cell fate and cell shape in the vertebrate nervous system. Genes Dev 14:2919-2937. CrossRef Medline

Cavanaugh JE, Ham J, Hetman M, Poser S, Yan C, Xia Z (2001) Differential regulation of mitogen-activated protein kinases ERK1/2 and ERK5 by neurotrophins, neuronal activity, and cAMP in neurons. J Neurosci 21: 434-443. Medline

Cheng PL, Song AH, Wong YH, Wang S, Zhang X, Poo MM (2011) Selfamplifying autocrine actions of BDNF in axon development. Proc Natl Acad Sci U S A 108:18430-18435. CrossRef Medline

Chiappalone M, Bove M, Vato A, Tedesco M, Martinoia S (2006) Dissociated cortical networks show spontaneously correlated activity patterns during in vitro development. Brain Res 1093:41-53. CrossRef Medline

Chinenov Y, Kerppola TK (2001) Close encounters of many kinds: Fos-Jun interactions that mediate transcription regulatory specificity. Oncogene 20:2438-2452. CrossRef Medline

Cohen E, Ivenshitz M, Amor-Baroukh V, Greenberger V, Segal M (2008) Determinants of spontaneous activity in networks of cultured hippocampus. Brain Res 1235:21-30. CrossRef Medline

Davies AM, Wright EM (1995) Neurotrophic factors: neurotrophin autocrine loops. Curr Biol 5:723-726. CrossRef Medline

Dong M, Wu Y, Fan Y, Xu M, Zhang J (2006) c-fos modulates brain-derived neurotrophic factor mRNA expression in mouse hippocampal CA3 and dentate gyrus neurons. Neurosci Lett 400:177-180. CrossRef Medline

Eferl R, Wagner EF (2003) AP-1: a double-edged sword in tumorigenesis. Nat Rev Cancer 3:859-868. CrossRef Medline

Feise RJ (2002) Do multiple outcome measures require p-value adjustment? BMC Med Res Methodol 2:8. CrossRef Medline

Gaiddon C, Loeffler JP, Larmet Y (1996) Brain-derived neurotrophic factor stimulates AP-1 and cyclic AMP-responsive element dependent transcriptional activity in central nervous system neurons. J Neurochem 66: 2279-2286. Medline

Ghosh A, Carnahan J, Greenberg ME (1994) Requirement for BDNF in activity-dependent survival of cortical neurons. Science 263:1618-1623. CrossRef Medline

Girgert R, Wittrock J, Pfister S, Schweizer P (2003) Farnesyltransferase inhibitor FTI-277 prevents autocrine growth stimulation of neuroblastoma by BDNF. J Cancer Res Clin Oncol 129:227-233. Medline

Greer PL, Greenberg ME (2008) From synapse to nucleus: calciumdependent gene transcription in the control of synapse development and function. Neuron 59:846-860. CrossRef Medline

Grimm R, Schicknick H, Riede I, Gundelfinger ED, Herdegen T, Zuschratter W, Tischmeyer W (1997) Suppression of c-fos induction in rat brain impairs retention of a brightness discrimination reaction. Learn Mem 3:402-413. CrossRef Medline

Griswold MD, Kim JS, Tribley WA (2001) Mechanisms involved in the homologous down-regulation of transcription of the follicle-stimulating hormone receptor gene in Sertoli cells. Mol Cell Endocrinol 173:95-107. CrossRef Medline

Halazonetis TD, Georgopoulos K, Greenberg ME, Leder P (1988) c-Jun dimerizes with itself and with c-Fos, forming complexes of different DNA binding affinities. Cell 55:917-924. CrossRef Medline

Hansen MR, Zha XM, Bok J, Green SH (2001) Multiple distinct signal pathways, including an autocrine neurotrophic mechanism, contribute to the survival-promoting effect of depolarization on spiral ganglion neurons in vitro. J Neurosci 21:2256-2267. Medline

Herdegen T, Leah JD (1998) Inducible and constitutive transcription factors in the mammalian nervous system: control of gene expression by Jun, Fos and Krox, and CREB/ATF proteins. Brain Res Brain Res Rev 28: 370-490. CrossRef Medline

Ho R, Eggert A, Hishiki T, Minturn JE, Ikegaki N, Foster P, Camoratto AM, Evans AE, Brodeur GM (2002) Resistance to chemotherapy mediated by TrkB in neuroblastomas. Cancer Res 62:6462-6466. Medline

Huang EJ, Reichardt LF (2001) Neurotrophins: roles in neuronal development and function. Annu Rev Neurosci 24:677-736. CrossRef Medline

Jiang X, Tian F, Mearow K, Okagaki P, Lipsky RH, Marini AM (2005) The excitoprotective effect of $N$-methyl-D-aspartate receptors is mediated by a brain-derived neurotrophic factor autocrine loop in cultured hippocampal neurons. J Neurochem 94:713-722. CrossRef Medline

Kairisalo M, Korhonen L, Sepp M, Pruunsild P, Kukkonen JP, Kivinen J, Timmusk T, Blomgren K, Lindholm D (2009) NF- $\kappa$ B-dependent regulation of brain-derived neurotrophic factor in hippocampal neurons by X-linked inhibitor of apoptosis protein. Eur J Neurosci 30:958-966. CrossRef Medline

Karin M, Liu Zg, Zandi E (1997) AP-1 function and regulation. Curr Opin Cell Biol 9:240-246. CrossRef Medline

Karpova NN, Rantamäki T, Di Lieto A, Lindemann L, Hoener MC, Castrén E (2010) Darkness reduces BDNF expression in the visual cortex and induces repressive chromatin remodeling at the BDNF gene in both hippocampus and visual cortex. Cell Mol Neurobiol 30:1117-1123. CrossRef Medline

Koppel I, Tuvikene J, Lekk I, Timmusk T (2015) Efficient use of a translation start codon in BDNF exon I. J Neurochem 134:1015-1025. CrossRef Medline

Krüttgen A, Möller JC, Heymach JV Jr, Shooter EM (1998) Neurotrophins induce release of neurotrophins by the regulated secretory pathway. Proc Natl Acad Sci U S A 95:9614-9619. CrossRef Medline

Kuribara M, Hess MW, Cazorla M, Roubos EW, Scheenen WJ, Jenks BG (2011) Brain-derived neurotrophic factor stimulates growth of pituitary melanotrope cells in an autocrine way. Gen Comp Endocrinol 170:156161. CrossRef Medline

Kuzniewska B, Rejmak E, Malik AR, Jaworski J, Kaczmarek L, Kalita K (2013) Brain-derived neurotrophic factor induces matrix metalloproteinase-9 expression in neurons via serum response factor/c-Fos pathway. Mol Cell Biol 33:2149-2162. CrossRef Medline

Lauterborn JC, Rivera S, Stinis CT, Hayes VY, Isackson PJ, Gall CM (1996) Differential effects of protein synthesis inhibition on the activity-dependent expression of BDNF transcripts: evidence for immediate-early gene responses from specific promoters. J Neurosci 16:7428-7436. Medline

Lee W, Mitchell P, Tjian R (1987) Purified transcription factor AP-1 interacts with TPA-inducible enhancer elements. Cell 49:741-752. CrossRef Medline

Lu B (2003) BDNF and activity-dependent synaptic modulation. Learn Mem 10:86-98. CrossRef Medline

Lu B, Pang PT, Woo NH (2005) The yin and yang of neurotrophin action. Nat Rev Neurosci 6:603-614. CrossRef Medline

Metsis M, Timmusk T, Arenas E, Persson H (1993) Differential usage of multiple brain-derived neurotrophic factor promoters in the rat brain following neuronal activation. Proc Natl Acad Sci U S A 90:8802-8806. CrossRef Medline

Miranda RC, Sohrabji F, Toran-Allerand CD (1993) Neuronal colocalization of mRNAs for neurotrophins and their receptors in the developing central nervous system suggests a potential for autocrine interactions. Proc Natl Acad Sci U S A 90:6439-6443. CrossRef Medline

Okamoto H, Shino Y, Hashimoto K, Kumakiri C, Shimizu E, Shirasawa H, Iyo M (2003) Dynamic changes in AP-1 transcription factor DNA binding activity in rat brain following administration of antidepressant amitriptyline and brain-derived neurotrophic factor. Neuropharmacology 45:251-259. CrossRef Medline

Olive M, Krylov D, Echlin DR, Gardner K, Taparowsky E, Vinson C (1997) A dominant negative to activation protein-1 (AP1) that abolishes DNA 
binding and inhibits oncogenesis. J Biol Chem 272:18586-18594. CrossRef Medline

Park H, Poo MM (2013) Neurotrophin regulation of neural circuit development and function. Nat Rev Neurosci 14:7-23. CrossRef Medline

Patel LR, Curran T, Kerppola TK (1994) Energy transfer analysis of Fos-Jun dimerization and DNA binding. Proc Natl Acad Sci U S A 91:7360-7364. CrossRef Medline

Pérez-Cadahía B, Drobic B, Davie JR (2011) Activation and function of immediate-early genes in the nervous system. Biochem Cell Biol 89: 61-73. CrossRef Medline

Pruunsild P, Kazantseva A, Aid T, Palm K, Timmusk T (2007) Dissecting the human BDNF locus: bidirectional transcription, complex splicing, and multiple promoters. Genomics 90:397-406. CrossRef Medline

Pruunsild P, Sepp M, Orav E, Koppel I, Timmusk T (2011) Identification of cis-elements and transcription factors regulating neuronal activitydependent transcription of human BDNF gene. J Neurosci 31:3295-3308. CrossRef Medline

Radler-Pohl A, Gebel S, Sachsenmaier C, König H, Krämer M, Oehler T, Streile M, Ponta H, Rapp U, Rahmsdorf HJ (1993) The activation and activity control of AP-1 (fos/jun). Ann N Y Acad Sci 684:127-148. CrossRef Medline

Raivich G, Behrens A (2006) Role of the AP-1 transcription factor c-Jun in developing, adult and injured brain. Prog Neurobiol 78:347-363. CrossRef Medline

Reichardt LF (2006) Neurotrophin-regulated signalling pathways. Philos Trans R Soc Lond B Biol Sci 361:1545-1564. CrossRef Medline

Rothman KJ (1990) No adjustments are needed for multiple comparisons. Epidemiology 1:43-46. CrossRef Medline

Salerno KM, Jing X, Diges CM, Cornuet PK, Glorioso JC, Albers KM (2012) Sox11 modulates brain-derived neurotrophic factor expression in an exon promoter-specific manner. J Neurosci Res 90:1011-1019. CrossRef Medline

Seldeen KL, McDonald CB, Deegan BJ, Farooq A (2009) Single nucleotide variants of the TGACTCA motif modulate energetics and orientation of binding of the Jun-Fos heterodimeric transcription factor. Biochemistry 48:1975-1983. CrossRef Medline

Shaulian E, Karin M (2001) AP-1 in cell proliferation and survival. Oncogene 20:2390-2400. CrossRef Medline

Sheng M, Greenberg ME (1990) The regulation and function of c-fos and other immediate early genes in the nervous system. Neuron 4:477-485. CrossRef Medline

Streiner DL, Norman GR (2011) Correction for multiple testing: is there a resolution? Chest 140:16-18. CrossRef Medline

Tao X, Finkbeiner S, Arnold DB, Shaywitz AJ, Greenberg ME (1998) Ca2+ influx regulates BDNF transcription by a CREB family transcription factor-dependent mechanism. Neuron 20:709-726. CrossRef Medline

Thress K, Macintyre T, Wang H, Whitston D, Liu ZY, Hoffmann E, Wang T, Brown JL, Webster K, Omer C, Zage PE, Zeng L, Zweidler-McKay PA (2009) Identification and preclinical characterization of AZ-23, a novel, selective, and orally bioavailable inhibitor of the Trk kinase pathway. Mol Cancer Ther 8:1818-1827. CrossRef Medline

Timmusk T, Palm K, Metsis M, Reintam T, Paalme V, Saarma M, Persson H (1993) Multiple promoters direct tissue-specific expression of the rat BDNF gene. Neuron 10:475-489. CrossRef Medline

Timmusk T, Belluardo N, Persson H, Metsis M (1994) Developmental regulation of brain-derived neurotrophic factor messenger RNAs transcribed from different promoters in the rat brain. Neuroscience 60 : 287-291. CrossRef Medline

Wang L, Chang X, She L, Xu D, Huang W, Poo MM (2015) Autocrine action of BDNF on dendrite development of adult-born hippocampal neurons. J Neurosci 35:8384-8393. CrossRef Medline

West AE, Chen WG, Dalva MB, Dolmetsch RE, Kornhauser JM, Shaywitz AJ, Takasu MA, Tao X, Greenberg ME (2001) Calcium regulation of neuronal gene expression. Proc Natl Acad Sci U S A 98:11024-11031. CrossRef Medline

West AE, Pruunsild P, Timmusk T (2014) Neurotrophins: transcription and translation. Handb Exp Pharmacol 220:67-100. CrossRef Medline

Wibrand K, Messaoudi E, Håvik B, Steenslid V, Løvlie R, Steen VM, Bramham CR (2006) Identification of genes co-upregulated with Arc during BDNF-induced long-term potentiation in adult rat dentate gyrus in vivo. Eur J Neurosci 23:1501-1511. CrossRef Medline

Willems E, Leyns L, Vandesompele J (2008) Standardization of real-time PCR gene expression data from independent biological replicates. Anal Biochem 379:127-129. CrossRef Medline

Wirth MJ, Brun A, Grabert J, Patz S, Wahle P (2003) Accelerated dendritic development of rat cortical pyramidal cells and interneurons after biolistic transfection with BDNF and NT4/5. Development 130:5827-5838. CrossRef Medline

Yasuda M, Fukuchi M, Tabuchi A, Kawahara M, Tsuneki H, Azuma Y, Chiba Y, Tsuda M (2007) Robust stimulation of TrkB induces delayed increases in BDNF and Arc mRNA expressions in cultured rat cortical neurons via distinct mechanisms. J Neurochem 103:626-636. CrossRef Medline

Zhang J, Zhang D, McQuade JS, Behbehani M, Tsien JZ, Xu M (2002) c-fos regulates neuronal excitability and survival. Nat Genet 30:416-420. CrossRef Medline

Zheng F, Wang H (2009) NMDA-mediated and self-induced bdnf exon IV transcriptions are differentially regulated in cultured cortical neurons. Neurochem Int 54:385-392. CrossRef Medline 